\title{
8. PHYSICAL PROPERTIES OF SEDIMENTS AND CORRELATIONS WITH ACOUSTIC STRATIGRAPHY: LEG 35, DEEP SEA DRILLING PROJECT
}

\author{
Brian E. Tucholke, Lamont-Doherty Geological Observatory of Columbia University, Palisades, New York \\ and \\ N. Terence Edgar and Robert E. Boyce, Scripps Institution of Oceanography, La Jolla, California
}

\section{INTRODUCTION}

The purpose of this report is to summarize the physical properties measurements made on sediments obtained during Leg 35, to note correlations between lithology and physical properties, and to discuss the relationships between these factors and the acoustic characteristics of the basin sediments.

Only a limited amount of time was available for drilling at each site, and in most cases this necessitated coring at widely spaced intervals. Thus the physical properties data can be used only to outline certain trends and major variations in the basin sediments, and they are usually insufficient for detailed interpretations. The physical properties measurements discussed here were all made at sea, and they are summarized in Tables 1 through 4 . The types of data obtained and the accuracy of the measurements are briefly outlined below. Corrections for salt content are not made in any of the calculations.

\section{METHODS}

\section{Sonic Velocity}

Measurements of compressional-wave velocity in consolidated sediments were made using the Hamilton frame velocimeter; this instrument and its operation are fully described by Boyce (1973). Before we reached the first site, repeated measurements on lucite and aluminum standards of known velocity indicated that the oscilloscope was not precisely calibrated. Therefore the following correction factors, determined from measurements on the standards, were applied to all measured values of velocity.

\begin{tabular}{|c|c|c|}
\hline Microsec/cm & & \\
\hline 1.0 & for all $V_{m}$ & $\mathrm{~V}_{\mathrm{m}} \times 1.009=\mathrm{V}_{\mathrm{t}}$ \\
\hline 2.0 & $\begin{array}{l}\text { for } V_{\mathrm{m}}<3.0 \mathrm{~km} / \mathrm{sec}, \\
\text { for } \mathrm{V}_{\mathrm{m}}>3.0 \mathrm{~km} / \mathrm{sec} \text {, }\end{array}$ & $\begin{array}{l}\mathrm{V}_{\mathrm{m}} \times 1.011=\mathrm{V}_{\mathrm{t}} \\
\mathrm{V}_{\mathrm{m}} \times 1.037=\mathrm{V}_{\mathrm{t}}\end{array}$ \\
\hline 5.0 & $\begin{array}{l}\text { for } V_{m}<3.0 \mathrm{~km} / \mathrm{sec} \text {, } \\
\text { for } V_{m}>3.0 \mathrm{~km} / \mathrm{sec} \text {, }\end{array}$ & $\begin{array}{l}\mathrm{V}_{\mathrm{m}} \times 0.988=\mathrm{V}_{\mathrm{t}} \\
\mathrm{V}_{\mathrm{m}} \times 1.008=\mathrm{V}_{\mathrm{t}}\end{array}$ \\
\hline 10.0 & $\begin{array}{l}\text { for } V_{m}<3.0 \mathrm{~km} / \mathrm{sec} \text {, } \\
\text { for } V_{m}>3.0 \mathrm{~km} / \mathrm{sec} \text {, }\end{array}$ & $\begin{array}{l}\mathrm{V}_{\mathrm{m}} \times 0.991=\mathrm{V}_{\mathrm{t}} \\
\mathrm{V}_{\mathrm{m}} \times 1.013=\mathrm{V}_{\mathrm{t}}\end{array}$ \\
\hline
\end{tabular}

where $\mathrm{V}_{\mathrm{m}}=$ measured compressional wave velocity and $\mathrm{V}_{\mathrm{t}}=$ true (corrected) compressional wave velocity.

Repeat measurements on sediment samples during the leg indicated that the precision of the measurements was normally $\pm 1 \%$ and always within $3 \%$. The latter percentage is higher than normal and results from the difficulty in picking the break on the oscilloscope when the ship's thrusters and heavy seas caused excessive vibration.

Sonic velocity measurements were made only on "undisturbed" or very slightly disturbed sediment samples. There are consequently very few measurements on sediments from the upper 200 meters of any of the drill sites, where coring disturbance was normally severe. All samples were removed from the core liners prior to measurement and were kept immersed in water until they equilibrated with laboratory temperatures of $19^{\circ}$. $21^{\circ} \mathrm{C}$ (about 2-3 hr). Except for velocity determinations on basalt, samples were trimmed by hand or with a diamond saw to provide flat, smooth surfaces against the transducers in the Hamilton frame. Wherever possible, velocities were measured both parallel and perpendicular to the bedding, and in some cases they were measured in three orthogonal directions. After velocities were measured, the samples were normally used for static GRAPE measurements and for direct determination of water content, porosity, saturated bulk density, and grain density.

\section{Gamma-Ray Attenuation Porosity Evaluator}

Wet-bulk densities of sediment and rock can be determined aboard Glomar Challenger using a Gamma Ray Attenuation Porosity Evaluator (GRAPE). The GRAPE was developed and described by Evans (1965), and its geologic applications were developed directly by Evans and by Harms and Choquette (1965); the basic principles involved were also studied independently by Tittman and Wahl (1965), Wahl et al. (1964), and Schlumberger (1972). Earlier studies independent of the GRAPE system used by DSDP are found in the reference lists of Evans (1965), Harms and Choquette (1965), and Tittman and Wahl (1965), and later independent studies have been by Keller (1965), Preiss et al. (1968), Brier et al. (1969), and Meyers et al. (1973), among others. The equipment used on Glomar Challenger has been discussed by Boyce (1973) and more recent modifications are discussed in Boyce (in press).

The basic GRAPE system consists of a drive device to move a core between a shielded gamma-ray source ( ${ }^{133} \mathrm{Ba}$ using the 0.3 and $0.359 \mathrm{MeV}$ energy levels) and a shielded scintillation detector. An analog computer immediately calculates "corrected" wet-bulk density (using a single attenuation coefficient, theoretically that of quartz) based on the attenuation of gamma-rays through the sediment and on other measured parameters. The GRAPE analog equipment (Evans, 1965) measures, calculates, and plots "corrected" wetbulk density on an analog graph. In the continuous mode, the core moves $1.6 \mathrm{~mm}$ per second through a 
TABLE 1

Site 322 Summary of Physical Properties

\begin{tabular}{|c|c|c|c|c|c|c|c|c|c|c|c|}
\hline \multirow{2}{*}{$\begin{array}{c}\text { Sample } \\
\text { (Interval } \\
\text { in } \mathrm{cm})\end{array}$} & \multirow{2}{*}{$\begin{array}{l}\text { Estimated } \\
\text { Depth } \\
(\mathrm{m})\end{array}$} & \multicolumn{2}{|c|}{$\begin{array}{l}\text { Velocity } \\
(\mathrm{km} / \mathrm{sec})\end{array}$} & \multicolumn{2}{|c|}{$\begin{array}{l}\text { GRAPE Special } \\
\text { 2-Min. Count } \\
\text { Sat. Bulk } \\
\text { Density }(\mathrm{g} / \mathrm{cc})\end{array}$} & \multirow{2}{*}{$\begin{array}{l}\text { Sat. } \\
\text { Bulk } \\
\text { Density } \\
(\mathrm{g} / \mathrm{cc})\end{array}$} & \multirow{2}{*}{$\begin{array}{c}\text { Wet } \\
\text { Water } \\
\text { Content } \\
(\%)\end{array}$} & \multirow{2}{*}{$\begin{array}{r}\text { Grain } \\
\text { Density } \\
(\mathrm{g} / \mathrm{cc})\end{array}$} & \multirow{2}{*}{$\begin{array}{c}\text { Porosity } \\
(\%)\end{array}$} & \multirow{2}{*}{$\begin{array}{l}\text { Impedance } \\
\left(\mathrm{g} / \mathrm{cm}^{2} \mathrm{sec}\right) \\
\times 10^{6}\end{array}$} & \multirow[b]{2}{*}{ Lithology Remarks } \\
\hline & & || Beds & 1 Beds & || Beds & $\perp$ Beds & & & & & & \\
\hline $\begin{array}{l}1-1,0-15 \\
1-2,133 \\
1-2,131-135 \\
1-2,135-140 \\
2-1,140-150 \\
2-2,110-115 \\
3-1,30-40 \\
3-1,40-42 \\
3-1,47 \\
3-1,68 \\
4-2,22-24 \\
4-2,30-31 \\
4-2,135-150 \\
5-1,134-136 \\
5-1,136-137 \\
6-1,36-39 \\
6-1,134-136 \\
6-1,136-138 \\
7, \mathrm{CC} \\
9-2,139-142 \\
9, \mathrm{CC} \\
9, \mathrm{CC} \\
9, \mathrm{CC} \\
9, \mathrm{CC} \\
10-0,0-15 \\
10-1,46-48 \\
10-1,49 \\
10-1,105-107 \\
10-1,114 \\
11-1,49 \\
11-2,51-52 \\
11-4,10 \\
11-4,84 \\
11-4,124-125 \\
11-4,135-150 \\
11-5,71 \\
11-5,135-150 \\
11-6,13 \\
11-6,57-59 \\
12-1,75 \\
12-1,104 \\
12-1,104 \\
13-1,45 \\
12-1,45 \\
13 \\
13\end{array}$ & $\begin{array}{l}76.50 \\
79.83 \\
79.81 \\
79.85 \\
191.90 \\
193.10 \\
295.30 \\
295.40 \\
295.47 \\
295.68 \\
353.72 \\
353.80 \\
354.85 \\
391.34 \\
391.36 \\
437.86 \\
438.84 \\
438.86 \\
447.00 \\
468.89 \\
469.12 \\
469.05 \\
469.08 \\
469.14 \\
485.00 \\
485.96 \\
485.99 \\
486.55 \\
486.64 \\
504.49 \\
506.01 \\
508.60 \\
509.34 \\
509.74 \\
509.85 \\
510.71 \\
511.35 \\
511.63 \\
512.07 \\
514.25 \\
514.54 \\
514.54 \\
532.95 \\
532.95\end{array}$ & $\begin{array}{l}2.04 \\
2.03 \\
1.88 \\
2.02 \\
2.15 \\
2.24 \\
2.20\end{array}$ & $\begin{array}{l}2.21 \\
1.88 \\
1.87 \\
1.86 \\
1.87 \\
\\
1.79 \\
1.94 \\
2.04 \\
2.09\end{array}$ & $\begin{array}{l}1.91 \\
2.07\end{array}$ & $\begin{array}{l}1.71 \\
1.93 \\
1.79 \\
2.03\end{array}$ & $1.47^{\mathrm{a}}$ & $\begin{array}{l}25 \\
22 \\
22 \\
18 \\
22 \\
18 \\
20 \\
23\end{array}$ & $2.73^{\mathrm{a}}$ & $73^{\mathrm{a}}$ & $\begin{array}{r}3.50 \\
13.28 \\
13.71 \\
13.65 \\
13.36 \\
13.39\end{array}$ & $\begin{array}{l}\text { Diatom clay } \\
\text { Diatom clay } \\
\text { Diatom clay } \\
\text { Diatom clay } \\
\text { Clay clast in drill slurry } \\
\text { Disturbed silty clay } \\
\text { Soft diatom claystone } \\
\text { Soft diatom claystone } \\
\text { Soft diatom claystone } \\
\text { Soft diatom claystone } \\
\text { Claystone } \\
\text { Claystone } \\
\text { Claystone } \\
\text { Silty claystone } \\
\text { Silty claystone } \\
\text { Soft claystone } \\
\text { Soft claystone } \\
\text { Soft claystone } \\
\text { Sandstone } \\
\text { Silty sandstone } \\
\text { Sandstone } \\
\text { Sandstone } \\
\text { Claystone } \\
\text { Claystone } \\
\text { Disturbed clay } \\
\text { Silty claystone } \\
\text { Silty claystone } \\
\text { Silty sandstone } \\
\text { Silty sandstone } \\
\text { Silty sandstone } \\
\text { Silty sandstone } \\
\text { Silty sandstone } \\
\text { Claystone } \\
\text { Claystone } \\
\text { Claystone } \\
\text { Claystone } \\
\text { Claystone } \\
\text { Claystone } \\
\text { Claystone } \\
\text { Basalt } \\
\text { Basalt } \\
\text { Basalt } \\
\text { Basalt } \\
\text { Basalt }\end{array}$ \\
\hline
\end{tabular}

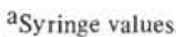

${ }^{b}$ Calculated using bulk density from $1-2,135-140 \mathrm{~cm}$.

pencil-size gamma beam, with the "corrected" density being continuously measured across the core. Potential errors resulting from (1) random gamma radiation, (2) standards, (3) liner thickness variation, (4) resolution, (5) diameter measurements, and (6) core disturbance are discussed in detail by Boyce (in press).

The analog data $( \pm 11 \%)$ and 2 -min count data $( \pm 2 \%)$ for Leg 35 were adjusted using equations of Boyce (in press). Corrections compensate for differences between the diameters of the core and core liner (Table 5) and result in calculation of true wet-bulk density values from the Evans (1965) "corrected" wet bulk density values. The variables used in these equations are for sediments, true grain density of $2.60 \mathrm{~g} / \mathrm{cc}$, "corrected" grain density of $2.60 \mathrm{~g} / \mathrm{cc}$, true fluid density of $1.025 \mathrm{~g} / \mathrm{cc}$, and "corrected" fluid density of $1.128 \mathrm{~g} / \mathrm{cc}$. A true and "corrected" grain density of $2.9 \mathrm{~g} / \mathrm{cc}$ was used for the basalt data. These equations adjust for the anomalous fluid density of seawater and assume the grains have the same attenuation coefficient as quartz.

The analog data were replaced by interpolating between two aluminum standards, applying needed geometric adjustments and applying adjustments for the anomalous "corrected" density of seawater. For the analog data a $6.61-\mathrm{cm}$ aluminum standard was assigned a density value of $2.60 \mathrm{~g} / \mathrm{cc}$ and a $2.54-\mathrm{cm}$ aluminum standard was assigned a value of $1.03 \mathrm{~g} / \mathrm{cc}$ and the data reduced by equations of Boyce (in press). For the 2-min density data an attenuation coefficient for each sample was determined by a linear interpolation between $0.10458 \mathrm{~cm}^{2} / \mathrm{g}$ and $0.10878 \mathrm{~cm}^{2} / \mathrm{g}$ for $6.61-$ and $2.54-\mathrm{cm}$ aluminum standards. This interpolation was made based on the thickness of the sample and is discussed in more detail by Boyce (in press). 
TABLE 2

Site 323 Summary of Physical Properties

\begin{tabular}{|c|c|c|c|c|c|c|c|c|c|c|c|}
\hline \multirow{2}{*}{$\begin{array}{l}\text { Sample } \\
\text { (Interval } \\
\text { in } \mathrm{cm} \text { ) }\end{array}$} & \multirow{2}{*}{$\begin{array}{l}\text { Estimated } \\
\text { Depth } \\
\text { (m) }\end{array}$} & \multicolumn{2}{|c|}{$\begin{array}{l}\text { Velocity } \\
(\mathrm{km} / \mathrm{sec})\end{array}$} & \multicolumn{2}{|c|}{$\begin{array}{l}\text { GRAPE Special } \\
\text { 2-Min Count } \\
\text { Sat. Bulk } \\
\text { Density }(\mathrm{g} / \mathrm{cc})\end{array}$} & \multirow{2}{*}{$\begin{array}{c}\text { Sat. } \\
\text { Bulk } \\
\text { Density } \\
(\mathrm{g} / \mathrm{cc})\end{array}$} & $\begin{array}{c}\text { Wet } \\
\text { Water } \\
\text { Content }\end{array}$ & $\begin{array}{c}\text { Grain } \\
\text { Density }\end{array}$ & Porosity & $\begin{array}{l}\text { Impedance } \\
\left(\mathrm{g} / \mathrm{cm}^{2} \mathrm{sec}\right)\end{array}$ & \\
\hline & & $\|$ Beds & 1 Beds & $\|$ Beds & 1 Beds & & $(\%)$ & $(\mathrm{g} / \mathrm{cc})$ & $(\%)$ & $\times 10^{5}$ & Lithology Remarks \\
\hline $1-1,125-128$ & 76.75 & & & & & & 42 & & & & Disturbed diatom clay \\
\hline $1-3,94$ & 79.44 & & & & & $1.52^{\mathrm{a}}$ & 44 & & & & Detrital diatom clay \\
\hline $1-5,5$ & 81.55 & & & & & $1.42^{\mathrm{a}}$ & 52 & $\begin{array}{l}2.60^{\mathrm{a}} \\
2.59^{\mathrm{a}}\end{array}$ & $74^{a}$ & & Disturbed clayey, diatom ooze \\
\hline $1-5,37$ & 81.87 & & & & & $1.39^{\mathrm{a}}$ & 56 & $2.81^{\mathrm{a}}$ & $\begin{array}{l}74^{4} \\
78^{a}\end{array}$ & & Disturbed clayey, diatom ooze \\
\hline $2-1,79-81$ & 161.79 & & & & & & 55 & & & & Clayey diatom ooze \\
\hline $2-1,79-81$ & 161.79 & & & & & 1.32 & 56 & 2.23 & 74 & & Clayey diatom ooze \\
\hline $2-1,84$ & 161.84 & & & & & & & & & $2.09^{b}$ & Clayey diatom ooze \\
\hline $2-1,93-98$ & 161.93 & & & & & & 56 & & & & Clayey diatom ooze \\
\hline $2-1,106-108$ & 162.06 & & & & & 1.65 & 43 & 3.26 & 71 & & Diatom-rich clay \\
\hline $2-1,120$ & 162.20 & & & & & & & & & 2.42 & Diatom-rich clay \\
\hline $3-1,106-107$ & 257.06 & & & & & 1.77 & 33 & 2.88 & 59 & & Silty claystone \\
\hline $3-1,108$ & 257.08 & 1.69 & 1.67 & & & & & & & 3.16 & Silty claystone \\
\hline $3-2,23$ & 257.73 & 1.73 & 1.66 & 1.87 & 1.82 & & & & & 3.05 & Silty claystone \\
\hline $3-2,73$ & 258.23 & & & & & $1.45^{\mathrm{a}}$ & 52 & $2.79^{\mathrm{a}}$ & $75^{\mathrm{a}}$ & & Diatom \\
\hline $3, \mathrm{CC}$ & 259.10 & & & & & $1.54^{\mathrm{a}}$ & 47 & $2.98^{\mathrm{a}}$ & $73^{a}$ & & Diatom \\
\hline $4, \mathrm{CC}$ & 316.10 & & & & & & 31 & & & & Disturbed clay \\
\hline $5-1,141$ & 333.41 & 1.67 & 1.62 & 1.82 & 1.82 & 1.90 & 33 & 3.39 & 62 & 3.02 & Claystone \\
\hline $5, \mathrm{CC}$ & 333.55 & & 1.63 & & 1.81 & 1.79 & 31 & 2.79 & 66 & 3.03 & Claystone \\
\hline $6-1,140$ & 342.90 & & & & & 1.61 & 40 & 2.68 & 64 & & Clayey diatomite \\
\hline $6-1,144$ & 342.94 & 1.73 & 1.69 & 1.60 & 1.58 & & & & & 2.70 & Clayey diatomite \\
\hline $6, \mathrm{CC}$ & 343.05 & 1.73 & 1.66 & 1.62 & 1.62 & 1.57 & 42 & 2.65 & 66 & 2.74 & Clayey diatomite \\
\hline $7-1,140$ & 361.40 & 1.71 & 1.65 & 1.62 & 1.64 & 1.53 & 41 & 2.46 & 63 & 2.67 & Diatom-rich claystone \\
\hline $7-2,113$ & 362.63 & 1.75 & 1.66 & 1.74 & 1.68 & 1.66 & 37 & 2.46 & 63 & 3.16 & Claystone gall \\
\hline $7-3,31.46$ & 363.31 & & & & & & 32 & & & & Disturbed clay \\
\hline $8-1,106$ & 409.06 & & & & & 1.76 & 29 & 2.58 & 52 & 3.04 & Claystone \\
\hline $8-1,146$ & 409.46 & 1.76 & 1.67 & 1.77 & 1.81 & 1.79 & 29 & 2.61 & 51 & 2.76 & Claystone \\
\hline $8, \mathrm{CC}$ & 409.55 & & & & & & 28 & & & & Claystone \\
\hline $8, \mathrm{CC}$ & 409.60 & & & & & & 6 & & & & Chert \\
\hline $8, \mathrm{CC}$ & 409.65 & & & & & & & & & $8: 15$ & Chert \\
\hline $9-2,100$ & 458.00 & 1.77 & 1.71 & 1.83 & 1.87 & 1.81 & 26 & 2.55 & 48 & 3.20 & Claystone \\
\hline $9-2,133$ & 458.33 & 3.77 & 3.13 & 2.11 & 2.09 & & & & & 6.67 & Chert \\
\hline $9, \mathrm{CC}$ & 458.55 & & & & & & & & & 6.99 & Chert \\
\hline $10-1,142$ & 504.42 & 1.88 & 1.76 & 1.98 & 2.00 & 1.98 & 24 & 2.86 & 47 & 3.50 & Clayey siltstone \\
\hline $10-3,0-12$ & 506.00 & & & & & & 22 & & & & Claystone \\
\hline $10-3,62$ & 506.62 & 2.51 & 2.12 & 2.03 & 1.99 & & & & & 4.24 & Chert \\
\hline $10-3,124$ & 507.24 & & 2.21 & & 1.95 & & & & & 4.42 & Chert \\
\hline $11-1,0-10$ & 550.50 & & & & & & 22 & & & & Silty claystone \\
\hline $11-1,67$ & 551.17 & & 1.71 & & 1.86 & 1.89 & 26 & 2.72 & 48 & 3.27 & Silty claystone \\
\hline $12-1,101$ & 599.01 & 1.88 & 1.76 & 2.07 & 1.98 & 1.94 & 23 & 2.69 & 44 & 3.56 & Claystone \\
\hline $12-1,135-150$ & 599.35 & & & & & & 20 & & & & Disturbed clay \\
\hline $12-2,45$ & 599.95 & 1.94 & 1.88 & 2.06 & 1.98 & 1.96 & 21 & 2.61 & 40 & 3.78 & Claystone \\
\hline $13-5,135-150$ & 624.35 & & & & & & 17 & & & & Silty claystone \\
\hline $13-5,140$ & 624.40 & 1.92 & 1.84 & 2.07 & 2.07 & 2.01 & 20 & 2.72 & 41 & 3.88 & Claystone \\
\hline $13-5,145$ & 624.40 & 1.82 & 1.73 & & 2.06 & 2.02 & 21 & 2.78 & 43 & 3.62 & Clayey siltstone \\
\hline $13-6,138$ & 625.88 & 1.97 & 1.93 & 2.02 & 2.10 & 1.99 & 18 & 2.55 & 36 & 4.17 & Claystone \\
\hline $14-1,140-150$ & 637.40 & & & & & & 18 & & & & Claystone \\
\hline $14-2,34$ & 637.84 & 1.96 & 1.89 & 2.13 & 2.07 & 2.08 & 14 & 2.54 & 30 & 3.69 & Claystone \\
\hline $14, \mathrm{CC}$ & 639.05 & 1.80 & 1.72 & 1.96 & 2.04 & 2.00 & 25 & $3.03(?)$ & 51 & 3.50 & Fe claystone \\
\hline $15-1,79$ & 656.04 & 1.82 & 1.75 & 1.99 & 1.99 & 1.84 & 27 & 2.67 & 50 & 3.60 & Fe claystone \\
\hline $15-5,48$ & 661.73 & 1.80 & 1.70 & 1.95 & 2.02 & 1.86 & 28 & 2.79 & 52 & 3.54 & Fe claystone \\
\hline $15-5,140-150$ & 662.65 & & & & & & 22 & & & & Fe claystone \\
\hline $16-1,31$ & 664.81 & & & & & 2.10 & 19 & 2.86 & 41 & & Nanno claystone \\
\hline $16-1,38$ & 664.88 & 2.06 & 1.91 & 2.16 & 2.15 & & & & & 4.24 & Nanno claystone \\
\hline $16-2,63-65$ & 668.13 & & & & & 2.02 & 20 & 2.73 & 41 & & Fe claystone \\
\hline $16-3,135-150$ & 668.85 & & & & & & 24 & & & & Fe claystone \\
\hline $16-3,135-150$ & 668.85 & & & & & & 22 & & & & Fe claystone \\
\hline $16-4,148$ & 670.48 & & & & & 1.92 & 24 & 2.70 & 46 & & Fe claystone \\
\hline $17-6,143$ & 682.93 & & 1.84 & & 1.95 & 1.90 & 25 & 2.67 & 46 & 3.72 & Fe claystone \\
\hline $18-3,19-21$ & 696.19 & & & & & 1.99 & 23 & 2.86 & 47 & & Fe claystone \\
\hline $18-4,22$ & 697.72 & & & & & 1.91 & 24 & 2.66 & 45 & & Fe claystone \\
\hline $18-4,76$ & 698.26 & 1.90 & 1.82 & & & 1.87 & 26 & 2.67 & 48 & & Zeolitic claystone \\
\hline $18-4,135-150$ & 698.85 & & & & & & 21 & & & & Zeolitic claystone \\
\hline $18-5,125$ & 700.25 & & 1.80 & & 2.36 & 1.97 & 24 & 2.84 & 47 & 4.34 & Fe zeolitic claystone \\
\hline $18-6,18$ & 700.68 & 3.63 & 3.65 & & 2.54 & & & & & 9.23 & Basalt \\
\hline $19-1,112$ & 703.62 & 4.80 & 4.80 & 2.77 & & & & & & 13.25 & Basalt \\
\hline $19-2,4$ & 704.04 & 4.96 & 4.99 & & 2.91 & & & & & 14.42 & Basalt \\
\hline $19-3,65$ & 706.15 & 4.86 & 4.80 & 2.79 & 2.85 & & & & & 13.73 & Basalt \\
\hline $19-4,85$ & 707.85 & & & & & & & & & 12.57 & Basalt \\
\hline $19-4,85$ & 707.85 & & & & & & & & & 12.84 & Basalt \\
\hline $20-1,140$ & 713.40 & 5.18 & & 2.84 & & & & & & 14.71 & Basalt \\
\hline $20-1,140$ & 713.40 & 5.11 & & 2.86 & & & & & & 14.51 & Basalt \\
\hline $20-2,132$ & 714.82 & 5.24 & & 2.82 & & & & & & 14.67 & Across thin crack in basalt \\
\hline $20-2,132$ & 714.82 & 5.48 & & 2.80 & & & & & & 15.34 & Basalt \\
\hline $20, \mathrm{CC}$ & 715.40 & 5.36 & & 2.82 & & & & & & 14.95 & Basalt \\
\hline $20, \mathrm{CC}$ & 715.40 & 5.12 & & 2.81 & & & & & & 14.28 & Basalt \\
\hline
\end{tabular}

${ }^{\text {a Syringe values. }}$

${ }^{\mathrm{b}}$ Calculated using bulk density from $2-1,79-81 \mathrm{~cm}$. 
TABLE 3

Site 324 Summary of Physical Properties

\begin{tabular}{|c|c|c|c|c|c|c|c|c|c|c|c|}
\hline \multirow{2}{*}{$\begin{array}{c}\text { Sample } \\
\text { (Interval } \\
\text { in } \mathrm{cm} \text { ) }\end{array}$} & \multirow{2}{*}{$\begin{array}{l}\text { Estimated } \\
\text { Depth } \\
\text { (m) }\end{array}$} & \multicolumn{2}{|c|}{$\begin{array}{l}\text { Velocity } \\
(\mathrm{km} / \mathrm{sec})\end{array}$} & \multicolumn{2}{|c|}{$\begin{array}{l}\text { GRAPE Special } \\
\text { 2-Min Count } \\
\text { Sat. Bulk } \\
\text { Density }(\mathrm{g} / \mathrm{cc})\end{array}$} & \multirow{2}{*}{$\begin{array}{l}\text { Sat. } \\
\text { Bulk } \\
\text { Density } \\
(\mathrm{g} / \mathrm{cc})^{\mathrm{a}}\end{array}$} & \multirow{2}{*}{$\begin{array}{c}\text { Wet } \\
\text { Water } \\
\text { Content } \\
(\%)\end{array}$} & \multirow{2}{*}{$\begin{array}{l}\text { Grain } \\
\text { Density } \\
(\mathrm{g} / \mathrm{cc})^{\mathrm{a}}\end{array}$} & \multirow{2}{*}{$\begin{array}{c}\text { Porosity } \\
(\%)^{\mathrm{a}}\end{array}$} & \multirow{2}{*}{$\begin{array}{c}\text { Impedance } \\
\left(\mathrm{g} / \mathrm{cm}^{2} \mathrm{sec}\right) \\
\times 10^{5}\end{array}$} & \multirow[b]{2}{*}{ Lithology Remarks } \\
\hline & & $\|$ Beds & $\perp$ Beds & || Beds & $\perp$ Beds & & & & & & \\
\hline $\begin{array}{l}1-5,135-150 \\
2-1,113 \\
2-3,105 \\
2-6,0-15 \\
3-4,54 \\
3-5,0-15 \\
4-3,36 \\
4-4,0-15 \\
4-4,86 \\
5-2,135-150 \\
5-3,55 \\
6-6,139 \\
7-0,0-15 \\
7-1,73 \\
7-4,124 \\
8-2,135-150 \\
8-3,101 \\
8-3,110\end{array}$ & $\begin{array}{r}16.35 \\
48.63 \\
51.55 \\
55.00 \\
80.54 \\
81.50 \\
107.36 \\
108.50 \\
109.36 \\
135.35 \\
136.05 \\
150.89 \\
151.50 \\
152.43 \\
157.44 \\
173.35 \\
174.51 \\
174.60\end{array}$ & & 1.60 & & & $\begin{array}{l}1.56 \\
1.78 \\
1.75 \\
1.75 \\
1.83 \\
1.89\end{array}$ & $\begin{array}{l}44 \\
35 \\
33 \\
34 \\
31 \\
31 \\
26 \\
27 \\
30 \\
31 \\
31 \\
28 \\
24 \\
25 \\
27 \\
24 \\
26\end{array}$ & $\begin{array}{l}2.82 \\
3.04 \\
2.82 \\
2.87 \\
2.89 \\
\\
2.78 \\
\\
2.94 \\
\\
2.55 \\
2.83\end{array}$ & $\begin{array}{l}69 \\
62 \\
59 \\
60 \\
56 \\
\\
50 \\
\\
56 \\
\\
53 \\
53\end{array}$ & & $\begin{array}{l}\text { Intensely deformed clay } \\
\text { Intensely deformed clay } \\
\text { Intensely deformed clay } \\
\text { Intensely deformed clay } \\
\text { Intensely deformed clay } \\
\text { Intensely deformed clay } \\
\text { Moderately deformed clay } \\
\text { Moderately deformed clay } \\
\text { Moderately deformed clay } \\
\text { Slightly deformed clay } \\
\text { Slightly deformed clay } \\
\text { Slightly deformed clay } \\
\text { Gassy clay } \\
\text { Gassy clay } \\
\text { Gassy clay } \\
\text { Slightly deformed clay } \\
\text { Slightly deformed clay } \\
\text { Firm clay }\end{array}$ \\
\hline
\end{tabular}

${ }^{\text {a }}$ Syringe values.

TABLE 4

Site 325 Summary of Phy sical Properties

\begin{tabular}{|c|c|c|c|c|c|c|c|c|c|c|c|}
\hline \multirow{2}{*}{$\begin{array}{c}\text { Sample } \\
\text { (Interval } \\
\text { in } \mathrm{cm} \text { ) }\end{array}$} & \multirow{2}{*}{$\begin{array}{l}\text { Estimated } \\
\text { Depth } \\
\text { (m) }\end{array}$} & \multicolumn{2}{|c|}{$\begin{array}{l}\text { Velocity } \\
(\mathrm{km} / \mathrm{sec})\end{array}$} & \multicolumn{2}{|c|}{$\begin{array}{l}\text { GRAPE Special } \\
\text { 2-Min Count } \\
\text { Sat. Bulk } \\
\text { Density }(\mathrm{g} / \mathrm{cc})\end{array}$} & \multirow{2}{*}{$\begin{array}{l}\text { Sat. } \\
\text { Bulk } \\
\text { Density } \\
(\mathrm{g} / \mathrm{cc})^{\mathrm{a}}\end{array}$} & \multirow{2}{*}{$\begin{array}{c}\text { Wet } \\
\text { Water } \\
\text { Content } \\
(\%)\end{array}$} & \multirow{2}{*}{$\begin{array}{l}\text { Grain } \\
\text { Density } \\
(\mathrm{g} / \mathrm{cc})^{\mathrm{a}}\end{array}$} & \multirow{2}{*}{$\begin{array}{c}\text { Porosity } \\
(\%)^{\mathrm{a}}\end{array}$} & \multirow{2}{*}{$\begin{array}{c}\text { Impedance } \\
\left(\mathrm{g} / \mathrm{cm}^{2} \mathrm{sec}\right) \\
\times 10^{5}\end{array}$} & \multirow[b]{2}{*}{ Lithology Remarks } \\
\hline & & \| Beds & 1 Beds & \| Beds & 1 Beds & & & & & & \\
\hline $1-1,134-135$ & 35.34 & & & & & $1.56^{\mathrm{a}}$ & 44 & $2.84^{\mathrm{a}}$ & $69^{\mathrm{a}}$ & & Disturbed silty clay \\
\hline $1-3,135-150$ & 38.35 & & & & & $1.72^{\mathrm{a}}$ & 36 & $2.84^{\mathrm{a}}$ & $61^{\mathrm{a}}$ & & Disturbed silty clay \\
\hline $2-1,140-141$ & 168.40 & & & & & $1.86^{\mathrm{a}}$ & 27 & $2.75^{\mathrm{a}}$ & $51^{\mathrm{a}}$ & & Disturbed silty clay \\
\hline $3-2,70-71$ & 178.70 & & & & & $2.00^{\mathrm{a}}$ & 24 & $2.88^{\mathrm{a}}$ & $47^{\mathrm{a}}$ & & Disturbed silty clay \\
\hline $4-1,143-144$ & 291.93 & & & & & & 30 & & & & Claystone \\
\hline $4-2,23$ & 292.23 & 1.73 & 1.99 & 1.70 & 1.79 & & & & & 3.52 & $\begin{array}{l}\text { Clayey siltstone } \\
\text { Clayey siltstone }\end{array}$ \\
\hline $5-1,90-94$ & 405.40 & & 1.70 & & 1.77 & 1.77 & 30 & 2.62 & 53 & 3.01 & Claystone \\
\hline $5-1,117-120$ & 405.67 & & & & & & 28 & & & & Claystone \\
\hline $5-1,118$ & 405.68 & & & & & 1.79 & 29 & 2.64 & 52 & & Claystone \\
\hline $5-1,123-128$ & 405.73 & 2.31 & 2.13 & 1.92 & 1.91 & 1.89 & 24 & 2.61 & 45 & 4.13 & Silty claystone \\
\hline $5-1,144-149$ & 405.94 & 5.22 & 5.05 & 2.68 & 2.64 & 2.47 & 5 & 2.68 & 13 & 13.58 & Calcite-cemented siltstone \\
\hline $5-1,144-149$ & 405.94 & 5.37 & 5.24 & 2.68 & 2.64 & & & & & 14.10 & Calcite-cemented siltstone (Run 2) \\
\hline $5-1,144-149$ & 405.94 & 5.33 & 5.27 & 2.68 & 2.64 & & & & & 14.18 & Calcite-cemented siltstone (Run 3) \\
\hline $6-1,138$ & 481.88 & & & & & 1.69 & & 2.52 & 54 & & Silty claystone \\
\hline $6-1,138-140$ & 481.88 & & & & & & 32 & & & & Silty claystone \\
\hline $7-2,73$ & 519.23 & 1.95 & 1.87 & & 1.84 & & 29 & & & 3.44 & Claystone \\
\hline $7-2,88$ & 519.38 & & & & & 1.92 & 21 & 2.57 & 41 & & Claystone \\
\hline $7-2,105-109$ & 519.55 & 2.76 & 2.37 & $\begin{array}{l}1.92 \mathrm{~A} \\
1.86 \mathrm{~B}\end{array}$ & $\mid \begin{array}{l}2.01 \mathrm{~A}^{\mathrm{b}} \\
1.84 \mathrm{~B}\end{array}$ & & 21 & & & 4.65 & Silty claystone \\
\hline $7-2,140-150$ & 519.90 & & & & & & 20 & & & & Silty claystone \\
\hline $8-1,81-86$ & 613.31 & 2.07 & 1.96 & 2.09 & 2.01 & & & & & 3.94 & Silty claystone \\
\hline $8-1,84-86$ & 613.34 & & & & & 1.93 & 21 & 2.57 & 41 & & Silty claystone \\
\hline $8-1,133$ & 613.83 & & & & & 1.89 & 22 & 2.53 & 42 & & Claystone \\
\hline $8-2,145-150$ & 615.45 & & & & & & 22 & & & & Claystone \\
\hline $9-1,133-150$ & 642.33 & & & & & & 18 & & & & Silty claystone \\
\hline $9-2,109-110$ & 643.59 & & 2.32 & & 2.02 & & & & & 4.78 & Sandstone \\
\hline $9-2,132-133$ & 643.82 & & 2.04 & & 2.01 & & & & & 4.18 & Claystone \\
\hline $10-2,0-15$ & 710.00 & & & & & & 15 & & & & Sandstone \\
\hline $10-2,95-96$ & 710.95 & & 2.12 & & 2.16 & & & & & 4.56 & Claystone \\
\hline $10-2,113-114$ & 711.13 & & 2.02 & & 2.12 & & & & & 4.36 & Sandstone \\
\hline $10-3,146-147$ & 712.96 & & 3.56 & & 2.37 & & & & & 8.65 & Calcite-cemented conglomerate \\
\hline $10, \mathrm{CC}$ & 713.20 & 4.58 & 3.49 & 2.55 & 2.50 & & & & & 8.72 & Calcite-cemented sandstone \\
\hline $10 . \mathrm{CC}$ & 713.20 & 4.55 & 3.42 & 2.55 & 2.50 & & & & & 8.55 & Calcite-cemented sandstone (Run 2) \\
\hline
\end{tabular}

asyringe values.

${ }^{\mathrm{b}} \mathrm{A}=$ piece $\mathrm{A} ; \mathrm{B}=$ piece $\mathrm{B}$.

The 2-min technique employed during Leg 35 differed from that described by Boyce (in press) in that during Leg 35 a new air gamma count was not used with every gamma count through the sample. This will result in an unusual statistical variation in scatter diagrams.

Recovery from the upper few hundred meters of a drill hole is usually disturbed sediment with slurry along the sides of the core. These cores are included in the analog GRAPE sample, but the individual samples for static 2-min counts are taken from the center of the core where disturbance is minimal.

Within individual cores the upper sections are more disturbed than the lower sections, and individual sample densities taken in the lower core sections thus tend to 
TABLE 5

Geometric Condition of Leg 35 Cores as They Were Processed Through the GRAPE

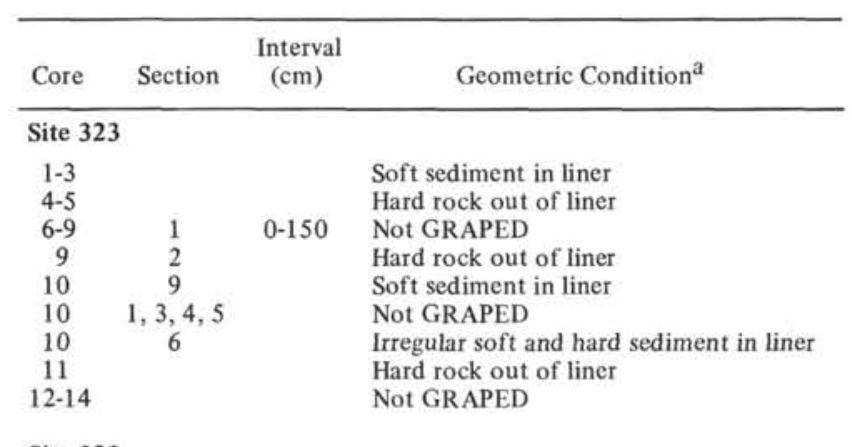

Site 323

$1-9$

$10-21$

Site 324

$1-10$

Site 325

1-7

$8-9$

Soft sediment in liner or not GRAPED Hard rock out of liner (GRAPED or not)

Soft sediment in liner or not GRAPED

\footnotetext{
${ }^{a}$ Soft sediment in liner: Completely filled core liner with soft sediment where no diameter adjustments are necessary.

Soft and hard sediment in liner: Alternating soft sediment and hard rock segments in core liner, with diameter adjustments applied for the hard rock segments. It is noted if the rock was surrounded by air, water, or sediment slurry.

Hard rock out of liner: Hard rock core segments removed from the core liners, cleaned, and placed on a strip of liner. The gamma beam axis and diameter of the hard rock offset $=3.305 \mathrm{~cm}$ - radius of rock.
}

compare more favorably with the analog GRAPE data than those taken from the upper core sections.

Since the cores include disturbed sediment, such as drilling slurry alternating with hard sediments or rocks, the graphical analog data should not be used without consulting the core photographs. It should also be pointed out that rock fragments lying in a slurry in a partially filled core may have been displaced during splitting or handling of the core subsequent to the GRAPE measurement.

\section{Saturated Bulk Density}

Saturated bulk density is calculated as:

$$
\rho_{b}=\frac{\text { (weight wet sediment })}{(\text { volume wet sediment })}=\mathrm{g} / \mathrm{cc}
$$

Three methods of measurement were employed. The first is the syringe technique whereby sediment volumes are determined using a graduated syringe, and weights are measured on a gimballed Cahn electrobalance. Because this technique is used in soft (and thus normally disturbed) sediment, and because sediment volumes dealt with are very small (less than $1.0 \mathrm{cc}$ ), the accuracy of saturated bulk densities determined in this manner is probably low $( \pm 5 \%)$. Bennett and Keller (1973) and Manheim et al. (1974) have further documented the inadequacies of this technique. The technique was used only in soft, unconsolidated sediment where other methods of volume determination were impractical.
At Site 323 a second method was used whereby sample volumes (usually $5-10 \mathrm{cc}$ ) were routinely determined by immersion in a graduated cylinder. The calculated precision of saturated bulk densities derived by this method is about $\pm 0.05 \mathrm{~g} / \mathrm{cc}$.

Finally, considerably improved results $( \pm 0.02 \mathrm{~g} / \mathrm{cc})$ were obtained at Site 325 through sample volume determination by Archimedes' principle (the difference between sample weight in air and in distilled water is numerically equal to volume).

\section{Water Content}

Water content is expressed here as percent wet weight:

$$
w(\%)=\frac{-(\text { (weight } \text { dry sediment }+ \text { salt })}{\text { (weight wet sediment })} \times 100 \%
$$

Consolidated sediment samples of 5-10 cc and syringe samples (unconsolidated sediment) of less than $0.5 \mathrm{cc}$ were used, and samples were normally dried at $110^{\circ} \mathrm{C}$ for $24 \mathrm{hr}$. The water content values from these two methods have a calculated precision of $\pm 1 \%$. In water content determination, where syringe volume errors do not enter the calculations, the syringe technique appears quite satisfactory (Manheim et al., 1974).

\section{Grain Density}

Grain densities were calculated using the formula

$$
\rho_{\mathrm{g}}=\frac{\text { (weight dry sediment }+ \text { salt })}{\begin{array}{c}
\text { (volume wet sediment } \\
- \text { volume evaporated water) }
\end{array}}=\mathrm{g} / \mathrm{cc}
$$

Three weight and volume measurements are used in the calculation which in turn increases possible errors. For the rock chunk techniques utilized at Sites 323 and 325, this amounts to a precision of \pm 0.12 and $\pm 0.05 \mathrm{~g} / \mathrm{cc}$, respectively. Although most of the syringe values reported here are reasonable and consistent, the very small syringe volumes used $(<0.5 \mathrm{cc})$ make effects of possible volume errors substantial. The porosity-density data are not meant to be used for determination of precise grain density values; at high porosity values the error in the grain density could be as much as $100 \%$ or as great as $20 \%$ for lower porosity values (less than $60 \%$ ). Therefore, grain densities calculated from syringe data are not considered reliable.

\section{Porosity}

Porosity is calculated as

$$
\mathrm{n} \%=\frac{\begin{array}{l}
\text { wt. evaporated water } \\
\text { density water }
\end{array}}{\text { volume wet sample }} \times 100
$$

on the assumption that the sample is completely saturated. The errors associated with measurement of this parameter are approximately $\pm 5 \%$ (absolute) for all syringe values, $\pm 2 \%$ for Site 323 rock-chunk values, and $\pm 1 \%$ for Site 325 rock-chunk values. 


\section{Acoustic Impedance}

Acoustic impedance is the product of saturated bulk density times velocity. GRAPE bulk densities (2-min count) were nearly always determined for velocity samples (and in the same orientations as velocity samples), and therefore the GRAPE values have been used in calculating impedance; exceptions were noted in Tables 1-4. Velocity and GRAPE density values used to calculate impedance are normally those measured perpendicular to bedding.

\section{PHYSICAL PROPERTIES AND LITHOLOGY}

\section{General Observations}

Biogenic material forms a relatively small part of the sediment cored on Leg 35 , so that the physical parameters measured are primarily those of terrigenous sediment. Of the biogenic component, diatoms are the most common form, but they normally constitute less than $25 \%$ of the sediment. Diatom oozes were infrequently recovered at Sites 323 and 324 . Diatoms persist in significant quantities to about 500 meters hole depth at Sites 323 and 325, and to about 360 meters at Site 322. At Site 324, Core $1(9.0-18.5 \mathrm{~m})$ recovered diatom clays and oozes, but the remaining 180 meters of sediment cored contained less than 5\% diatoms. Radiolarians and siliceous spicules have a similar distribution, but they rarely exceed $5 \%$ of the sediment.

Calcareous organisms occur even less frequently; calcareous foraminifera are common only in Core 1 at Site 325. Except for nannofossil claystones and chalks at 663-668 meters at Site 323, and at 519 and 615 meters at Site 325 , nannofossils occur only in trace quantities.

However, it is apparent that during sediment diagenesis, remobilization of biogenic silica and calcite in some units has created local lithologic changes and consequent sharp variations in physical properties. Several samples were tested for physical properties where authigenic silica and calcite have precipitated to form a cementing matrix (Table 5). These samples are discussed in the individual site descriptions below.

Most of the sediments recovered are interbedded terrigenous sands, silts, and clays. Clays and claystones are volumetrically most important in the sediment recovered, and the majority of physical properties measurements were made on such material. Unconsolidated gravels, sands, and silts were recovered in the upper, unconsolidated sediment and locally within the deeper, consolidated sediment at Sites 322, 323, and 325. The commonly low core-recovery ratio, however, provides indirect evidence that coarse, unconsolidated sediment is more common than indicated by the recovered sediment (Figure 1). It seems likely that a considerable amount of coarse sediment was lost through the dog-type core catcher during the coring process. It is noteworthy that the best core recovery occurs near the top and the bottom of the holes drilled. A possible explanation is that the soft clay seals coarser material into the core barrels in the upper parts of the holes, whereas the consolidated claystones at middepth do not. It is also possible that in the upper soft sediments only a few meters of penetration will fill the entire 10 -meter core barrel. In the deeper sections of the holes where the coarse material becomes cemented and more strongly consolidated, core recovery is again improved.

Sediments which appear to be dominantly of pelagic origin were recovered in a 3-meter interval above basalt at Site 322 and in a 62-meter interval above basalt at Site 323 . These are iron- and manganese-rich claystones in which terrigenous components are absent or occur only in trace quantities.

The major downward change in physical characteristics of the sediment in the Bellingshausen basin is the transition from unconsolidated to consolidated material. At all three sites where this boundary was penetrated $(322,323$, and 325$)$, the transition occurs roughly at 300 meters. Although consolidated and unconsolidated sediments were found locally above and below this depth, both the changes in coring/drilling rates and the core lithology indicate that the transition occurs near this level (Figures 2-5). The age of the sediment at the transition is late Miocene at Site 322, middle Miocene at Site 323, and Pliocene at Site 325. Thus it appears that in this region of primarily terrigenous sediments, sediment consolidation is largely a function of depth of burial and is independent of time of burial. A similar situation was noted by Keller and Bennett (1973) for abyssal-plain sites on DSDP Leg 16 in the east central Pacific. By way of contrast, Packham and van der Lingen (1973) found that the degree of lithification in highly calcareous sediments in the southwest Pacific is probably dependent in some way on both depth of burial and time; the latter is undoubtedly an important factor in diagenesis of the calcareous sequence.

In most cases the spot-coring on Leg 35 necessitated by time limitations allows only general observations about the trends in physical properties values. More detailed information, however, is available where closely spaced cores were taken in the bottom 75 and 100 meters of Sites 322 and 323, respectively, and at Site 324.

\section{Site 322 - Bellingshausen Abyssal Plain}

At Site 322 water content is highest in samples at 7680,193 , and 295 meters (Figure 2). These samples are diatomaceous clays, and it is apparent that the open test structure of the interspersed diatoms has considerably increased void space in this sediment compared to nondiatomaceous clays. The effect of diatoms in increasing the porosity, and consequently the water content, of Bellingshausen basin sediments is especially apparent when values from all four drill sites are considered (Figure 6).

The nondiatomaceous claystones at Site 322 exhibit a slight decrease in water content with depth and have values of $18 \%$ to $22 \%$ just above basalt. The water content of three sandstone samples in the lower 50 meters of the sediment column is comparable to that of the claystones.

Measured sonic velocities show a regular increase from $1.55 \mathrm{~km} / \mathrm{sec}$ at 80 meters to a median of about 2.0 $\mathrm{km} / \mathrm{sec}$ at 510 meters. The sandstone velocities in all cases are higher than those of claystones at comparable depths; one sandstone at 447 meters is of considerably higher velocity $(2.21 \mathrm{~km} / \mathrm{sec})$ than adjacent samples. We found no evidence of authigenic cementation in the samples, indicating that the higher velocities of sand- 

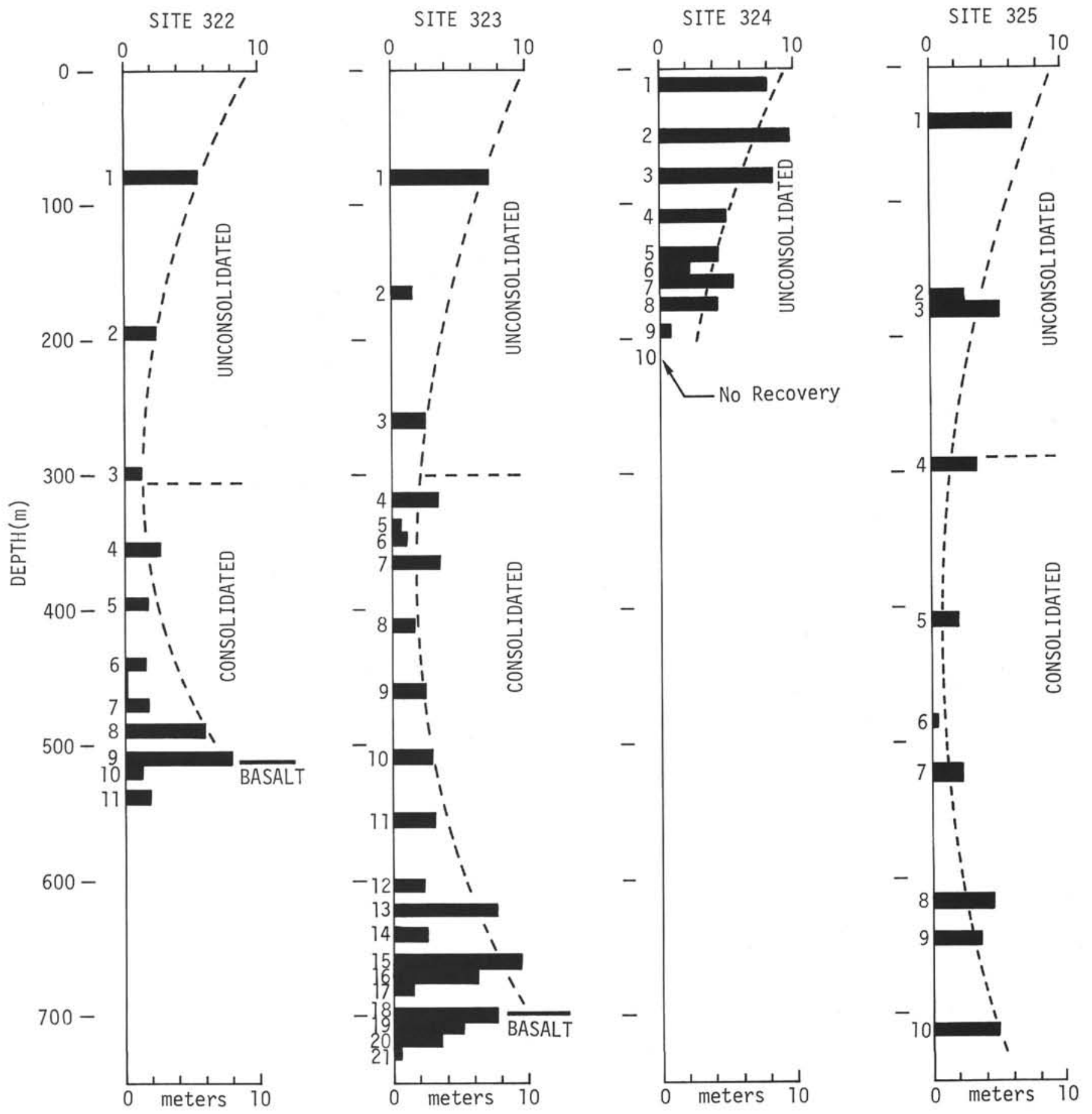

CORE RECOVERY VS. DEPTH

Figure 1. Core recovery $(m)$ versus depth in sediment column for sites drilled on Leg 35.

stones must be due to well-developed intergranular contact. These velocity differences may in part relate to differences in the solid-mineral velocity and to density and porosity. These observations of increasing velocity with increasing grain size are consistent with the velocity/grain size relationships discussed by Horn et al. (1968) and Hamilton (1970).

Basalt velocities range from 4.92 to $5.04 \mathrm{~km} / \mathrm{sec}$. The samples tested were fresh and had a low water content
$(0.83 \%)$; they are described by W. Vennum elsewhere in this volume.

\section{Site 323 - Bellingshausen Abyssal Plain}

Diatoms again have a pronounced effect in increasing the porosity and water content in the upper 360 meters of sediments at Site 323 (Figures 3 and 6). Samples analyzed above 250 meters were all diatomaceous and several nondiatomaceous as well as diatomaceous sam- 


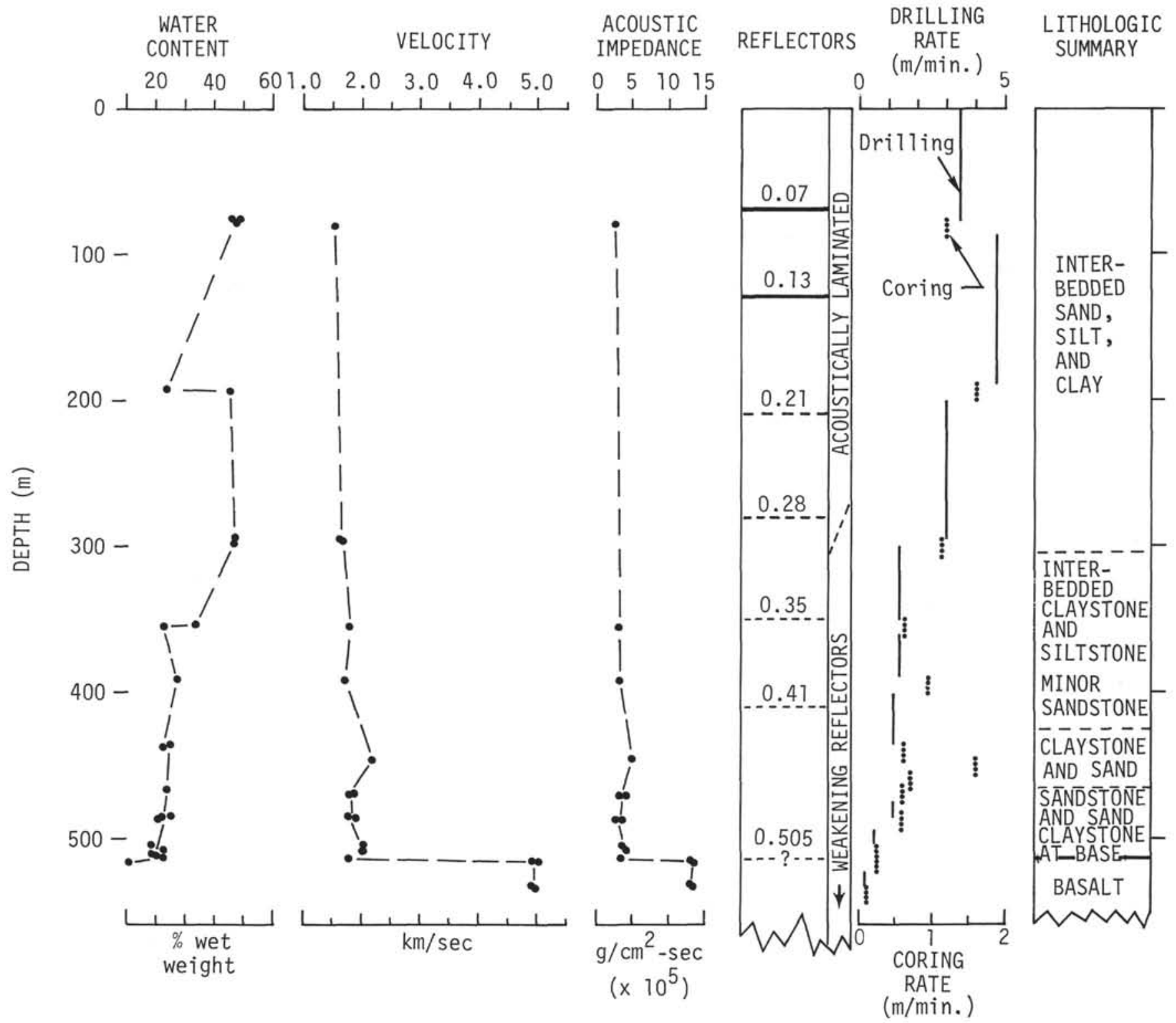

Figure 2. Summary of physical properties, acoustic character, and lithology of sediments at Site 22. Velocities are those measured perpendicular to bedding or on unoriented samples. Relative strength of reflectors is indicated by heavy solid lines (strongest) to dotted lines (weakest), and the depth of each reflector (in seconds reflection time) is indicated.

ples cored between 250 and 360 meters were tested. At 250 meters the diatomaceous and nondiatomaceous samples differed by about $15 \%$ in both water content and porosity, but the difference decreased with depth so that porosities were essentially the same at 360 meters, and water contents varied by only about $5 \%$. The decreasing void space with depth may be related to collapse of the diatom-clay lattice and crushing of the frustules. Consolidation tests on diatom oozes were made by Lee (1973); he suggested that at effective stresses exceeding $5-7 \mathrm{~kg} / \mathrm{cm}^{2}$, the crushing of diatom frustules may occur. Of course this stress value is highly variable and is sensitive to the sample's porosity, permeability, composition, grain size distribution, and cementation. In the sediments we studied, the diatoms are imbedded in a fine clay matrix comprising about $75 \%$ of the sediment.
In the nondiatomaceous clays, claystones, and siltstones, both porosity and water content show a progressive decrease down to 638 meters. The iron-rich claystones between this depth and basalt at 700 meters have slightly higher, uniform water contents of about $25 \%$ and porosities of $45 \%$ to $50 \%$. A nannofossil claystone in the middle of this unit has values $3 \%$ to $5 \%$ lower for both parameters.

The downhole variation in saturated bulk density is grossly complementary to that of water content and porosity (Figure 3). Slight departures from this relationship are probably caused by downhole variations in grain density (Table 2). The diatomaceous sediments have densities of less than $1.65 \mathrm{~g} / \mathrm{cc}$, and there is a steady density increase downhole to about $2.0 \mathrm{~g} / \mathrm{cc}$ at 638 meters. Slightly reduced densities (as low as 1.85 $\mathrm{g} / \mathrm{cc}$ ) occur in the iron-rich claystones in the lower 62 


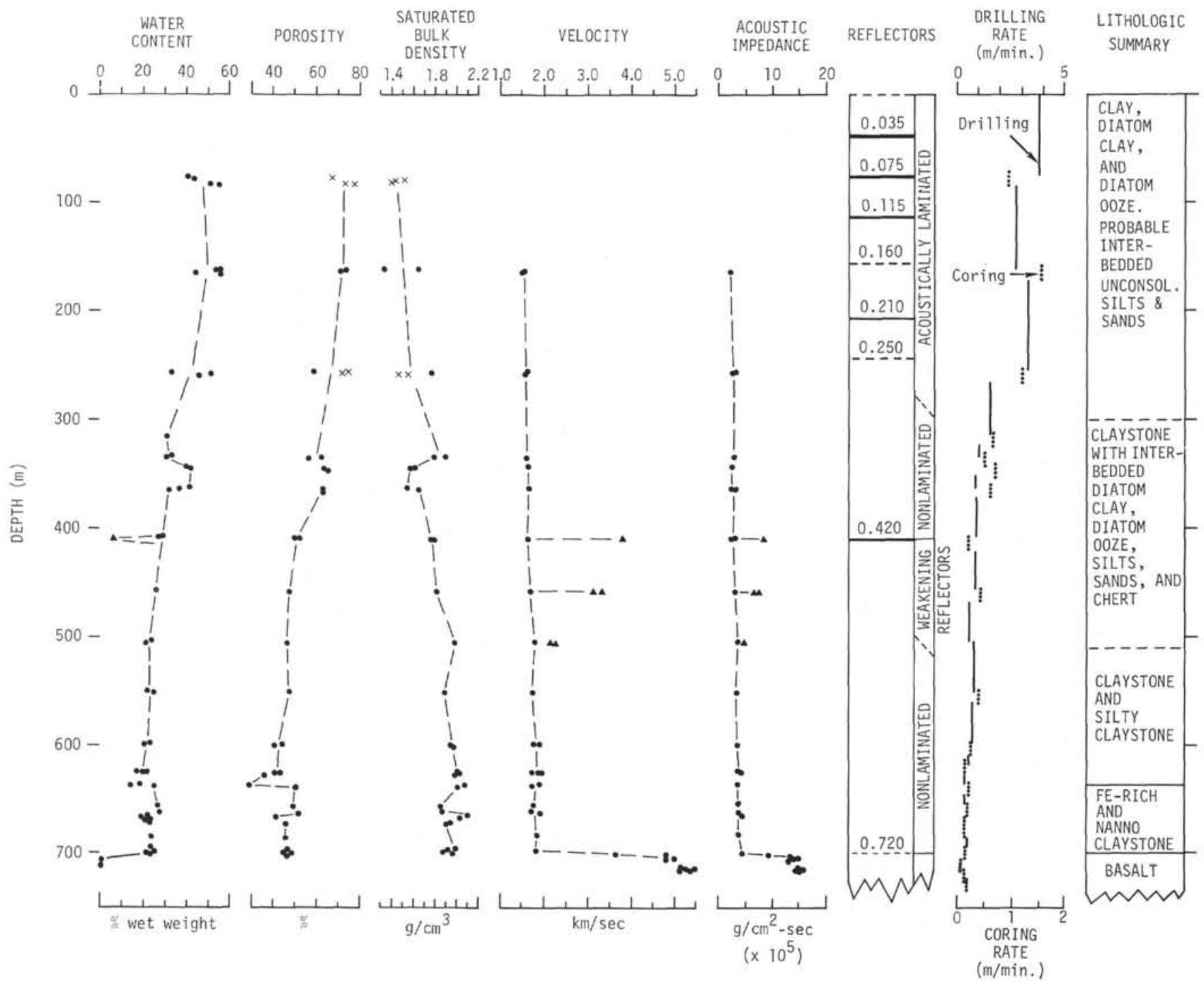

Figure 3. Summary of physical properties, acoustic character, and lithology of sediments at Site $323 . \quad$ Velocities and reflectors are as in Figure 2. Values determined by the syringe technique are marked by $x$; silicified claystones (cherts) are indicated by triangles.

meters of the hole, but the nannofossil claystone in this unit has a high density $(2.1 \mathrm{~g} / \mathrm{cc})$.

Measured sonic velocities show a remarkably steady increase with depth, from about $1.5 \mathrm{~km} / \mathrm{sec}$ at 160 meters to $1.8-1.9 \mathrm{~km} / \mathrm{sec}$ in the lowest 100 meters. The cherts (silicified claystones) which were encountered below 400 meters show the only marked deviation from this velocity trend. The highest measured velocity of $3.79 \mathrm{~km} / \mathrm{sec}$ was in the shallowest chert cored, whereas the deeper cherts showed decreasing velocities, with 2.12 $\mathrm{km} / \mathrm{sec}$ recorded for the silicified claystones at 507 meters. This velocity decrease appears to match a gradient of decreasing silicification downhole (see Site 323 Summary).

Velocities measured on basalt samples increased irregularly from $3.65 \mathrm{~km} / \mathrm{sec}$ in the topmost basalt to a maximum of $5.48 \mathrm{~km} / \mathrm{sec} 15$ meters deeper. The lower velocities near the top of the unit may relate to progressive alteration of the basalt (see Vennum, this volume). Static GRAPE measurements indicate that the sample with velocity $3.65 \mathrm{~km} / \mathrm{sec}$ has a bulk density of $2.54 \mathrm{~g} / \mathrm{cc}$, compared with densities greater than 2.63 $\mathrm{g} / \mathrm{cc}$ for deeper samples.

\section{Site 324 - Antarctic Continental Rise}

Hole collapse forced the termination of drilling at only 218 meters at Site 324. All the sediment recovered is unconsolidated clay with interbedded silt layers up to about $1 \mathrm{~cm}$ thick. Most of the sediment is strongly disturbed by coring, and only syringe samples were taken for measurement of physical properties.

Water content and porosity both decrease rapidly in the first 70 meters of hole, but at a lesser rate below (Figure 4). The values in the lower part of the hole $(25 \%$ water content and $50 \%$ porosity) approach those found at depths of several hundred meters at Sites 322 and 323. Diatoms are very rare in all the cores except Core 1, and their absence probably accounts for the low porosity and water content at these shallow depths. Saturated bulk density increases downhole, from $1.56 \mathrm{~g} / \mathrm{cc}$ at 16 


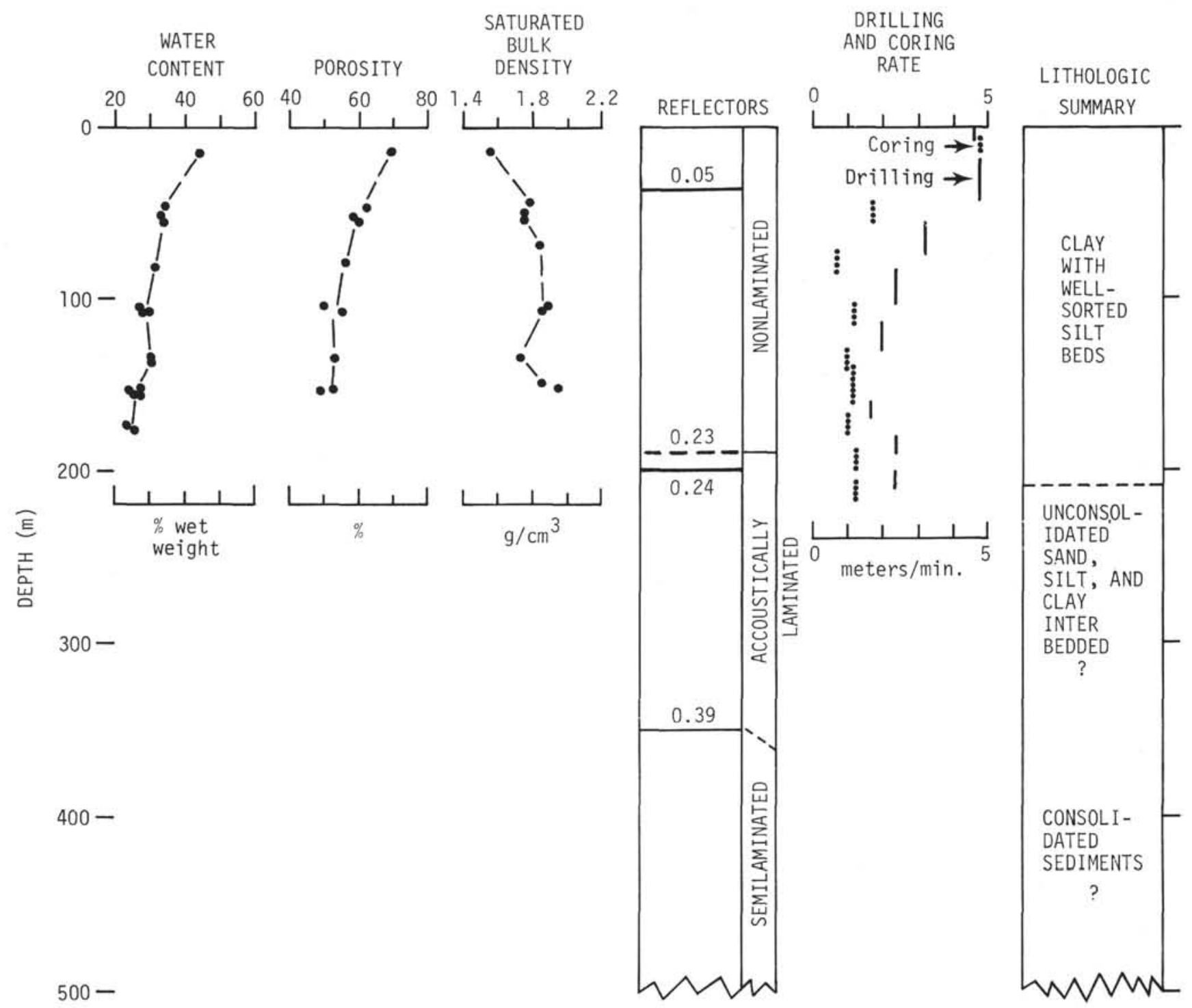

Figure 4. Summary of physical properties, acoustic character, and lithology of sediments at Site 324. Reflectors are as in Figure 2. All physical property values were determined by the syringe technique.

meters to about $1.9 \mathrm{~g} / \mathrm{cc}$ at 150 meters; the latter values also are comparable to those of deeper, diatom-free sediment at Sites 322 and 323.

Only one sonic velocity was measured at Site 324 , a value of $1.60 \mathrm{~km} / \mathrm{sec}$ in firm clay at 174.6 meters. Shallower velocity measurements were not made because of coring disturbance in the soft mud.

\section{Site 325 - Antarctic Continental Rise}

Only nondiatomaceous sediments were sampled for physical-properties measurements at Site 325, and most of them were clays or claystones. The sediments at this site consist of interbedded sands, silts, and clays and their consolidated analogs. However, there are common occurrences of siliceous cementation and, unlike the other sites, of well-developed calcite cementation (Table 6). Unfortunately, cores were recovered from widely spaced intervals, so that the distribution of these materials and variations in physical properties are only very broadly defined.
Aside from the shallowest measurements at $35-40$ meters, water contents and porosities are fairly constant at $25 \%$ to $35 \%$ and $45 \%$ to $55 \%$, respectively, down to 500 meters (Figure 5). The shallow clay samples have $35 \%$ to $45 \%$ water content and $60 \%$ to $70 \%$ porosity. A calcite-cemented siltstone at 406 meters exhibits greatly decreased water content (5.3\%) and porosity (13\%), and in deeper samples calcite cementation undoubtedly has reduced both water content and porosity (Table 6).

Water content drops to about $15 \%$ to $20 \%$ and porosity to about $40 \%$ below 500 meters. Smear-slide examination of sediment in Cores 7 through 10 shows that minor recrystallized silica is common over this interval (see 325 Site Report), and the slight silica cementation has probably contributed to the reduction in void space.

Saturated bulk density of the sediment also increases slightly at these depths to values of 1.94-1.97 g/cc. Between 100 and 500 meters densities are quite variable, ranging from 1.7 to $2.0 \mathrm{~g} / \mathrm{cc}$, with a median of about 1.8 $\mathrm{g} / \mathrm{cc}$. In the poorly consolidated sediment at 35 to 40 


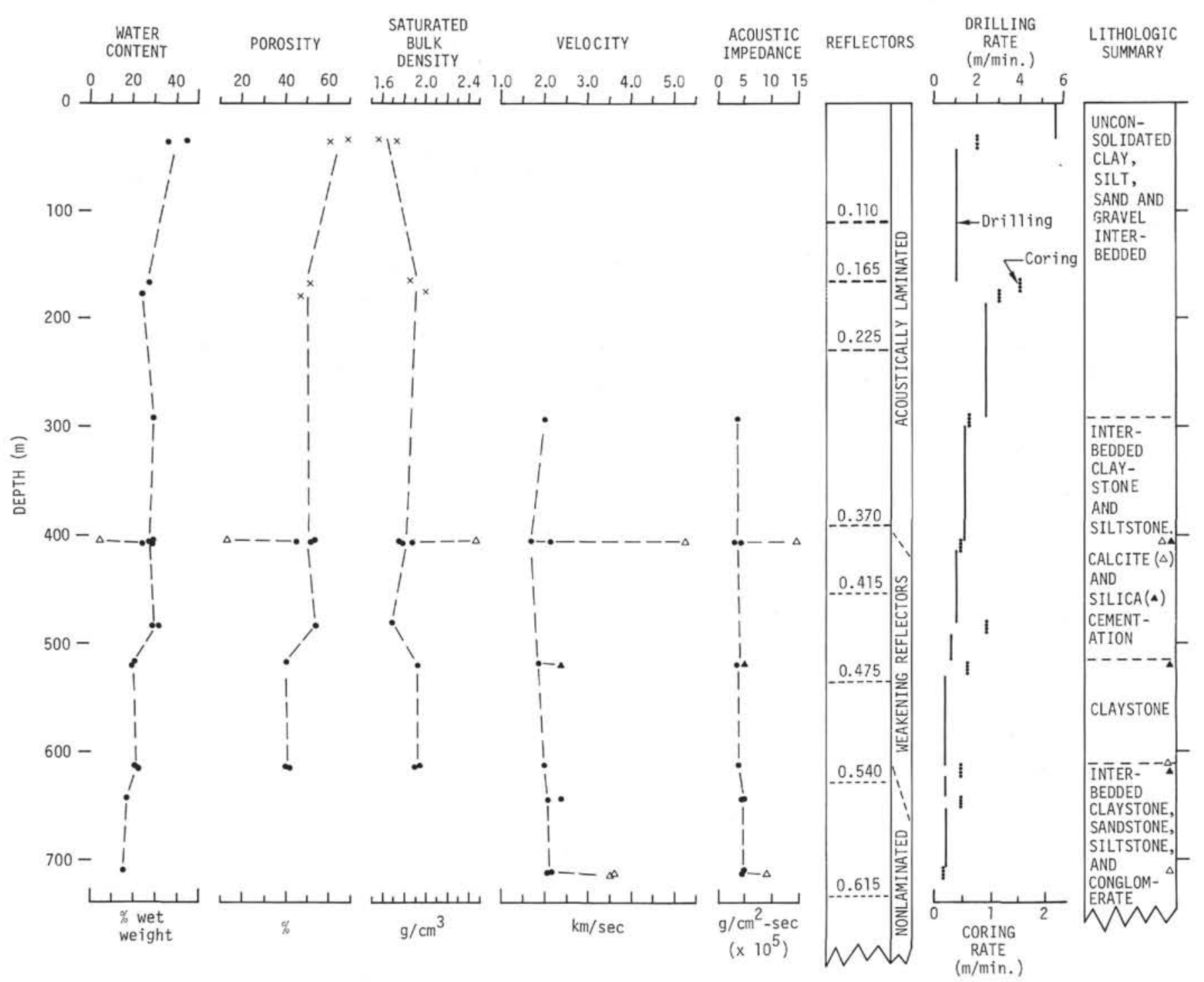

Figure 5. Summary of physical properties, acoustic character, and lithology of sediments at Site 325. For explanation see

Figures 2 and 3. Calcite-cemented samples are marked by open triangles.

meters the densities are less than $1.75 \mathrm{~g} / \mathrm{cc}$. The downhole saturated bulk-density values are virtually a mirror image of variations in water content and porosity (Figure 5).

Exclusive of diagenetically cemented sediments, values of sonic velocity show a general increase downhole. The calcite-cemented sediments in this hole have exceptionally high velocities; the siltstone at 406 meters was measured at $5.27 \mathrm{~km} / \mathrm{sec}$, and calcite-cemented conglomerate and sandstone at 713 meters have velocities of 3.56 and $3.49 \mathrm{~km} / \mathrm{sec}$, respectively. The claystone sample from 519.5 meters appears to owe its high velocity $(2.37 \mathrm{~km} / \mathrm{sec})$ to slight siliceous cementation.

\section{Velocity Anisotropy}

On most sediment samples tested for sonic velocity, measurements were made both perpendicular and parallel to the bedding planes. Only one sample from less than 200 meters depth was measured both perpen- dicular and parallel to bedding (322-1-2, $133 \mathrm{~cm}, 79.83$ $\mathrm{m})$, and within measurement error it exhibited no anisotropy. However, in the deeper, semilithified and lithified sediments virtually every sample exhibited velocity anisotropy with higher velocities parallel to the bedding (Figure 7). The consolidated sands, silts, and clays recovered have velocities up to about $2.15 \mathrm{~km} / \mathrm{sec}$ perpendicular to the bedding, and velocity parallel to bedding averages $5 \%$ higher for all three sediment types. No indication exists of an increase in velocity anisotropy with depth. However, velocity anisotropy was normally greater in cemented samples; the three silicified claystones which we measured exhibited an average 19\% velocity difference between the two orientations, and the calcite-cemented sandstone recovered from the bottom of Site 325 had a velocity which was $32 \%$ higher parallel to the bedding. A calcite-cemented siltstone cored higher in the same hole showed only a small $(<3 \%)$ anisotropy. Although the sandstone had prominent bedding and the siltstone was poorly bedded, the develop- 
B. E. TUCHOLKE, N. T. EDGAR, R. E. BOYCE

WATER CONTENT (\% wet weight)

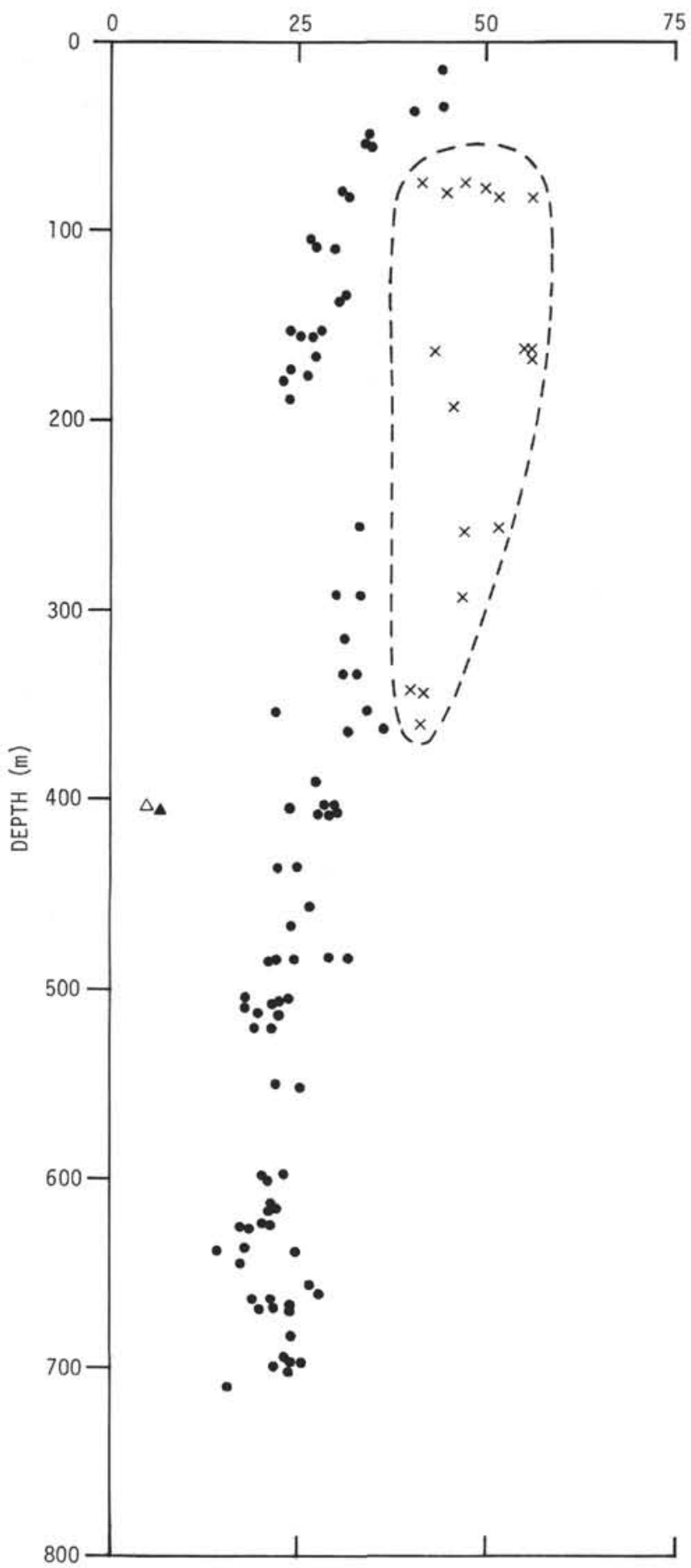

POROSITY (\%)

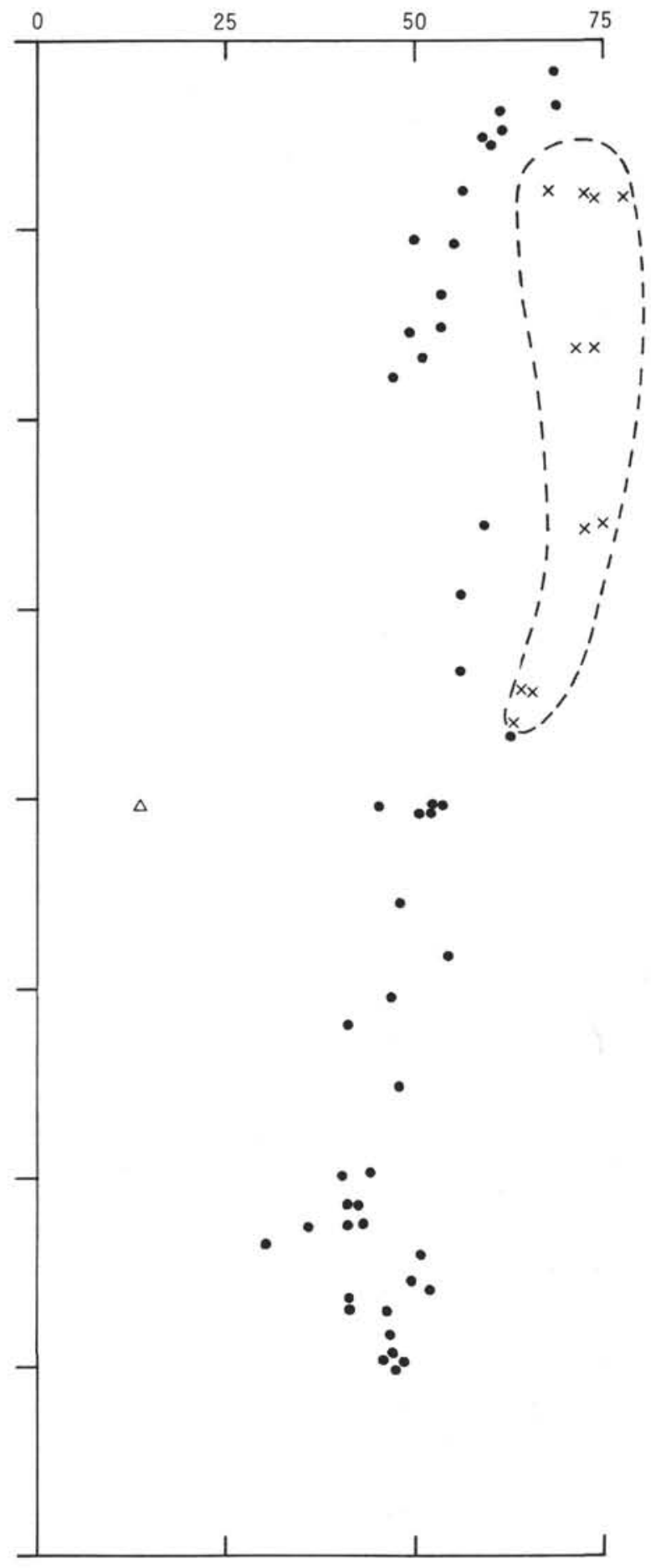

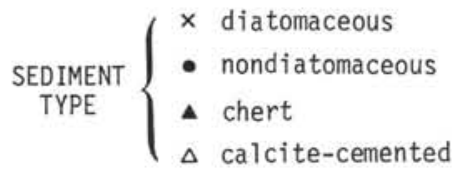

ALL SITES - LEG 35

Figure 6. Compilation of water content and porosity versus depth for the four sites drilled on Leg 35 . Diatom clays and oozes are indicated by $x$ 's, cherts by solid triangles, and calcite-cemented samples by open triangles. 
TABLE 6

Occurrences of Recrystallized Silica and Calcite

\begin{tabular}{|c|c|c|}
\hline $\begin{array}{c}\text { Sample } \\
\text { (Interval in } \mathrm{cm} \text { ) }\end{array}$ & $\begin{array}{l}\text { Estimated } \\
\text { Depth }(\mathrm{m})\end{array}$ & Material \\
\hline \multicolumn{3}{|l|}{ Site 323} \\
\hline $5-1,135$ & 333.35 & Thin calcite vein in claystone \\
\hline $7-1,95$ & 360.95 & $\begin{array}{l}\text { Calcite-cemented qtz. sandstone } \\
\text { chip }\end{array}$ \\
\hline $8-1,110-120$ & 409.10 & Silicified claystone \\
\hline $8, \mathrm{CCa}$ & 409.60 & Silicified claystone \\
\hline $9-2,117-140^{\mathrm{a}}$ & 458.17 & Silicified claystone \\
\hline 9. CC $^{\mathrm{a}}$ & 458.55 & Silicified claystone \\
\hline $10-1,92-96$ & 503.92 & Silicified claystone \\
\hline $10-2,4-6$ & 504.54 & Silicified claystone \\
\hline $10-2,12-14$ & 504.62 & Silicified claystone \\
\hline $10-2,135-138$ & 505.85 & Silicified claystone \\
\hline $10-3,62-63^{a}$ & 506.62 & Silicified claystone \\
\hline $10-3,124-125^{a}$ & 507.24 & Silicified claystone \\
\hline $13-3,140$ & 621.40 & $\begin{array}{l}\text { Calcite-cemented qtz. siltstone } \\
\text { chip }\end{array}$ \\
\hline $13-6,36$ & 624.86 & $\begin{array}{l}\text { 3-mm lens calcite-cemented qtz. } \\
\text { siltstone }\end{array}$ \\
\hline $13-6,51$ & 625.01 & $\begin{array}{l}\text { 3-mm lens calcite-cemented qtz. } \\
\text { siltstone }\end{array}$ \\
\hline $13, \mathrm{CC}$ & 626.05 & rxtl. calcite in siltstone \\
\hline \multicolumn{3}{|l|}{ Site 324} \\
\hline $8-2,70$ & 172.70 & Silicified clay gall \\
\hline $9-1,89-91$ & 190.39 & Silicified quartz silt \\
\hline $9-1,140(9, \mathrm{CC})$ & 190.90 & Silicified claystone \\
\hline \multicolumn{3}{|l|}{ Site 325} \\
\hline $5-1,75-77$ & 405.25 & Silicified claystone \\
\hline $5-1,144-149^{a}$ & 405.94 & Calcite-cemented siltstone \\
\hline $5, \mathrm{CC}$ & 407.60 & Silicified claystone \\
\hline $7-2,77$ & 519.27 & Silicified claystone \\
\hline $7, \mathrm{CC}$ & 521.60 & Silicified claystone \\
\hline $8-1,118-121$ & 613.68 & Calcite-cemented siltstone \\
\hline $8, \mathrm{CC}$ & 617.10 & Silicified claystone \\
\hline 8,9 , and 10 & $612.5-718.0$ & minor rxtl. silica in claystones \\
\hline $10-3,145-149^{a}$ & 712.95 & Calcite-cemented conglomerate \\
\hline $10, \mathrm{CC}^{\mathrm{a}}$ & 713.20 & Calcite-cemented sandstone \\
\hline
\end{tabular}

aphysical properties measured.

ment of bedding does not appear to explain the difference in anisotropy because the noncemented sandstones and siltstones, irrespective of bedding, all exhibit roughly a $5 \%$ velocity anisotropy. It may be that preferential calcite cementation in certain beds of the sandstone increases its anisotropy. In addition to preferential cementation, velocity anisotropy may also be related to anisotropic minerals aligned with bedding and to cracks or foliation across the sample.

A few claystones were measured for velocity in three orthogonal directions. The two measurements parallel to the beds were in each case identical within the limits of measurement error.

Several basalt samples were also checked for anisotropy, including the low-velocity sample from Site 323 which showed alteration. All of these samples proved to be essentially isotropic (Figure 7), again within the measurement error of the velocimeter.

\section{CORRELATION WITH SEISMIC PROFILES}

Attempts to correlate the results of drilling with the reflecting horizons observed in profiler records in this region are particularly difficult for several reasons. In most cases the spot coring failed to recover material from the probable depth of all but a few major reflectors; the generally poor core recovery further suggests that a substantial volume of coarse unconsolidated sediment, which was not recovered or tested for bulk physical characteristics, plays an important role in determining the seismic character of the basin sediments. At Sites 322 and 323 the complex pulse character of the acoustic signal interacting with the prominent stratification of the younger abyssal plain sediments not only confuses identification of major reflectors, but probably also masks reflectors and/or introduces spurious reflectors through signal interference. Recognition of deep reflectors is also hampered by poor signal penetration in the highly reflective sediments at Site 322 and in the very thick sediments at Site 325 .

Impedance (density $\times$ velocity) was calculated for cored sediments wherever velocity measurements were made. Impedance contrasts or mismatches are a primary factor in determining the amount of energy reflected (or lost) when an acoustic signal passes from one medium into another of higher impedance (Kinsler and Frey, 1962; Hamilton, 1970). Impedance mismatches which were found in the cored sediment therefore should create acoustic horizons at the drill sites.

In discussing the seismic profile records below, we use the terms laminated, semilaminated, and nonlaminated to indicate the presence or absence of acoustic reflectors; "stratified" refers to sedimentological parameters.

\section{Site 322}

Acoustic basement as seen in profiler records is very poorly defined in the vicinity of Site 322 . The basement produces no strong reflection and is best defined by the downward disappearance of any coherent reflectors, despite the strong acoustic impedance contrast across the sediment/basalt interface (Figure 2). Careful study of the full-scale Eltanin 43 profile, which passes within 3 $\mathrm{km}$ of the site, shows that acoustic basement is strongly irregular and suggests that Site 322 was drilled near the side of a deep fissure in basement (Figure 8). The sharp declivity of the basement and its poor definition as a reflector make it very difficult to pick its depth in reflection time on the Glomar Challenger profiler record (Figure 9). A very poorly defined reflector near 0.505 $\mathrm{sec}^{\mathrm{l}}$ subbottom appears in both the Challenger and Eltanin records at the site, and it may correspond to basaltic basement. Using this reflection time and the basement depth of 514 meters, the calculated average velocity for the sediment column is $2.03 \mathrm{~km} / \mathrm{sec}$.

Two on-site sonobuoys were attempted at Site 322, but neither drifted to sufficient range for determination of sediment velocities from the wide-angle reflections. No other sonobuoy records have been taken in the immediate area, although several sonobuoy profiles were make in similar acoustic/physiographic provinces to the southwest (Table 7). Although there is marked lateral velocity variation in sediments of the deep Bellings-

'This and all subsequent reflection times are two-way travel times. 


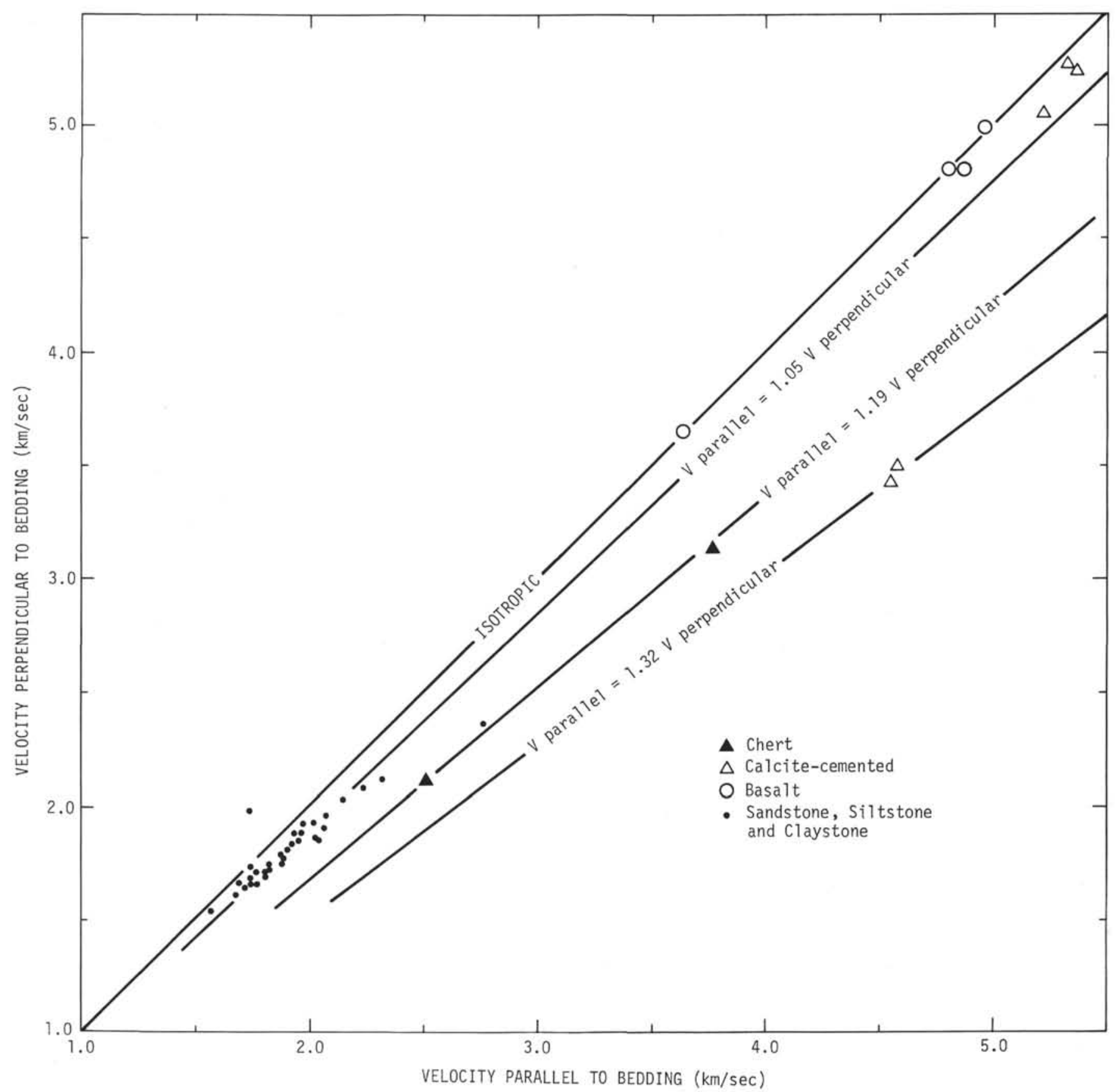

Figure 7. Velocity anisotropy of sediment samples from Sites 322, 323, and 325.

hausen Basin, the calculated figure of $2.03 \mathrm{~km} / \mathrm{sec}$ at Site 322 is in general agreement with these velocities.

The amplitude of reflectors diminishes regularly with depth at Site 322. Most of this decrease can probably be attributed to signal attenuation, although the consolidation of the deeper sediments and the apparent stabilization of their physical properties may contribute to the effect. The downward decrease in reflector strength is most marked below the clay/claystone transition at about 300 meters. Most of the sediments in the Bellingshausen basin show at least a slight decrease in amplitude of reflectors with depth, even in many areas where the shallower sediments have low reflectivity.
In addition to signal attenuation and the steepness of the sediment/basalt interface, small-scale basement roughness may also contribute to the poor reflectivity of the oceanic crust in this area. Rapid drilling and coring rates $(12-13 \mathrm{~m} / \mathrm{hr})$ in basement, and the texture and composition of the recovered basalt, suggest that the drill penetrated a fractured pile of hyaloclastites and pillow flows, possibly interbedded with sediments (see Vennum, this volume). Such an irregular, fractured surface could cause dispersion and absorption of the acoustic signal.

Because of the widely spaced cores at this site, there are insufficient data to attempt correlation between 


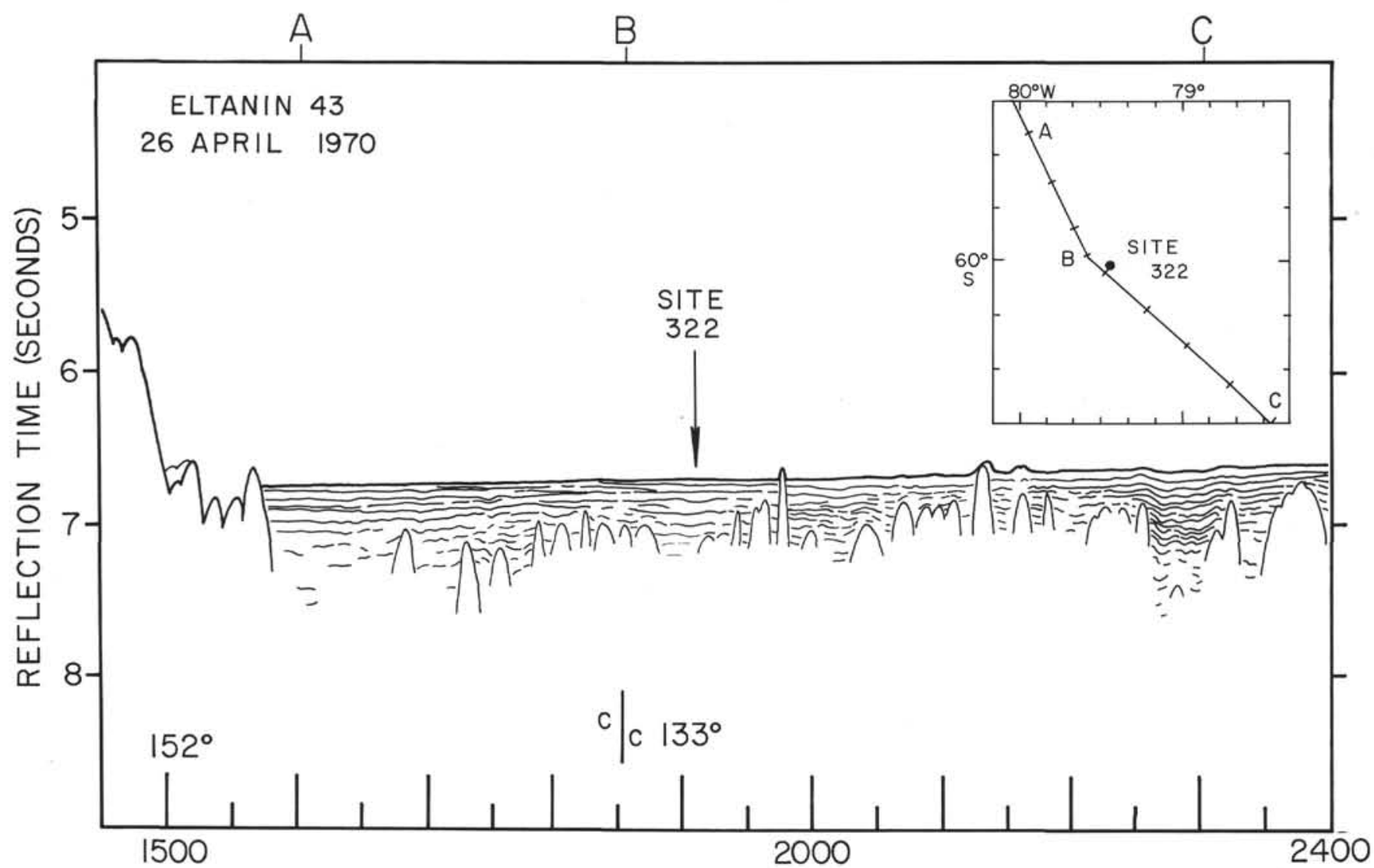

Figure 8. Tracing of Eltanin 43 seismic profiler record. The ship track passes within $3 \mathrm{~km}$ southwest of Site 322 on the Bellingshausen Abyssal Plain.

reflectors and physical properties changes. The only conclusion that appears to be justified is that reflector amplitude diminishes in the zone of consolidated sediments below 300 meters.

\section{Site 323}

Basalt was encountered at 700 meters subbottom at Site 323. In the Glomar Challenger profiler record it correlates with a reflector of moderate amplitude at $0.72 \mathrm{sec}$ beneath the sea floor (Figure 10), indicating an average sediment velocity of $1.95 \mathrm{~km} / \mathrm{sec}$. Two sonobuoy profiles recorded by Eltanin 42 on the Bellingshausen Abyssal Plain west of Site 323 suggest much lower velocities for the sediment column (Table 7), but it is apparent from both the reflector correlation and the measured sample velocities (Figure 3 ) that higher velocities pertain at Site 323.

The major acoustic horizon within the sedimentary sequence lies at $0.42 \mathrm{sec}$ subbottom, is sharp at its upper boundary, and is decreasingly reverberant over the next $0.15 \mathrm{sec}$ (Figures 10 and 11). There is little doubt that this acoustic horizon corresponds to the chert encountered in the hole and first recovered at 409.1 meters. However, the interval velocities calculated using this depth $(1.95 \mathrm{~km} / \mathrm{sec}$ above the chert and $1.94 \mathrm{~km} / \mathrm{sec}$ from chert to basement) are not consistent with the downhole velocity increase in directly measured samples (Figure 3 ). Thus it seems likely that the chert recovered at 409.1 meters actually came from a shallower depth in the hole between Cores 7 and 8 ( 370 to $408 \mathrm{~m}$ ); this interval was drilled ("washed") with the core barrel in the drill string so it is entirely possible that the chert was encountered here. More reasonable interval velocities are obtained if the first occurrence of chert was at a true depth of, say, 390 meters (1.86 and $2.07 \mathrm{~km} / \mathrm{sec}$ for the upper and lower intervals, respectively). Silicified claystones interlayered with claystones were recovered down to 507 meters, but the impedance contrast between these two sediment types decreases downhole (Figure 3). This may correlate with the downward-decreasing reverberation noted over these depth in the profiler record (Figure 10).

Except for the acoustic horizon just discussed, reflectors are weak or absent below about $0.3 \mathrm{sec}$ subbottom, and the consolidated sediments below about 300 meters correspond closely to this acoustic interval. The strong basement reflection below the nonlaminated sediments suggests that signal attenuation does not fully account for the absence of reflectors in the overlying sediment.

Only three cores were obtained from the acoustically laminated sediments comprising the upper 300 meters of the sediment column. Impedance contrasts caused by rapid velocity/density changes in the unconsolidated sand, silt, and clay interbeds of this interval account for the reverberant character of sediment in the upper 0.3 sec of the profiler record. Our data are inadequate to identify any individual reflectors within this depth interval. 


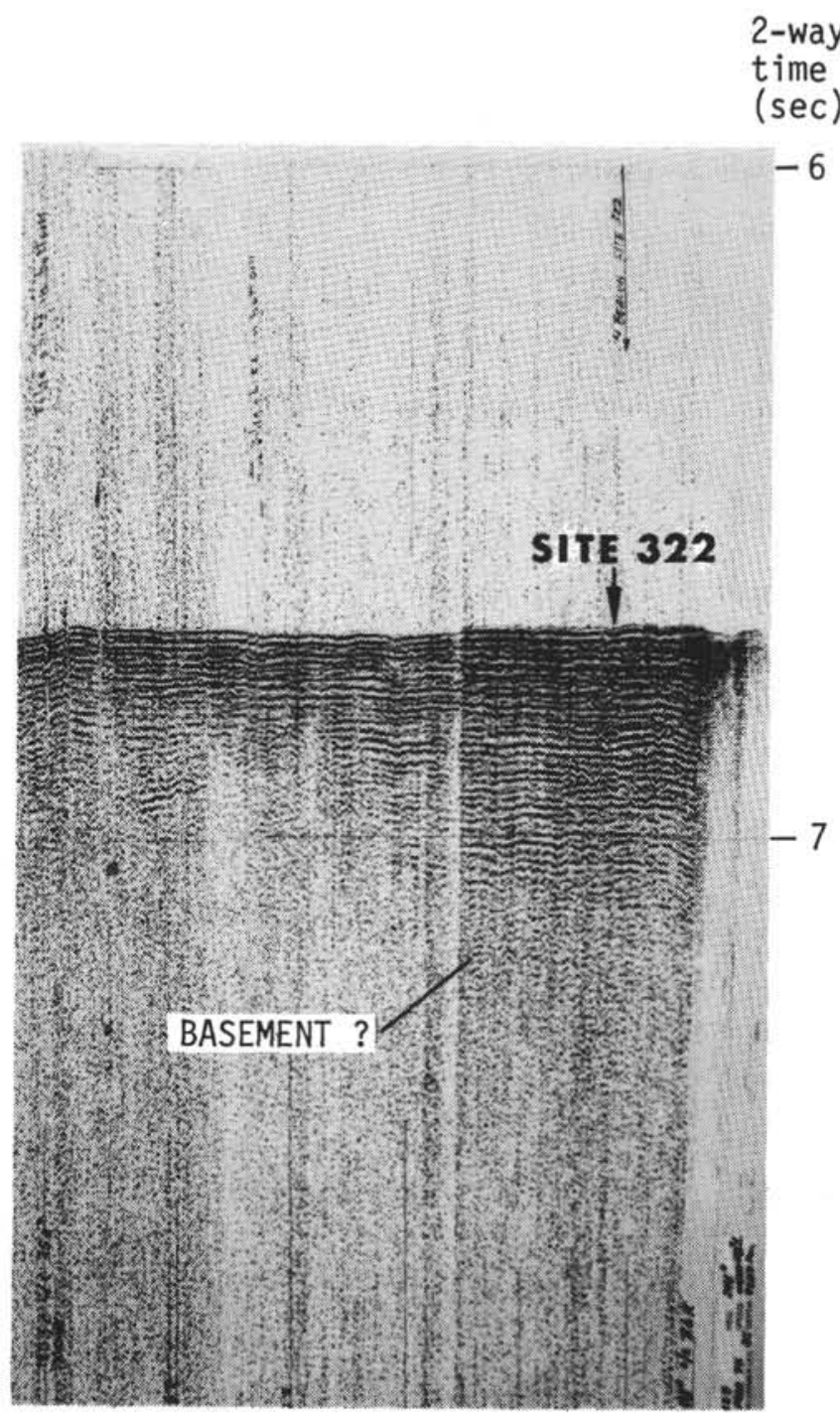

Figure 9. Glomar Challenger profiler record across Site 322 on the Bellingshausen Abyssal Plain.

\section{Site 324}

Site 324 was drilled 218 meters into a wedge of nonlaminated sediment on the continental rise (Figures 12 and 13). The prolonged, reverberant character of the airgun signal is repeated in the sea-floor reflection, but a single reflection event at about $0.05 \mathrm{sec}$ subbottom does not match the pulse character and appears to be a real reflector. Acoustically laminated sediment at about 0.23 sec subbottom underlies the sediment drilled.

Physical properties measurements were made only on the unconsolidated and slightly consolidated clays which comprise the bulk of sediment cored at Site 324 . Small samples of partially silicified quartz silt and claystone were recovered just below 190 meters in Core 9. The last core attempted at this site (Core 10) failed to recover any sediment except a trace of sand; this failure, and the high polish on the core barrel, suggest that a thick interval of unconsolidated sand was penetrated. Thus the sediments represented by Cores 9 and 10 are the first deviation from unconsolidated clayey sediment
TABLE 7

Sonobuoy Results for Sediments in Bellingshausen Basin ${ }^{\mathrm{a}}$

\begin{tabular}{|c|c|c|c|c|}
\hline Sonobuoy & Latitude & Longitude & $\begin{array}{c}\text { Layer } \\
\text { Velocity } \\
(\mathrm{km} / \mathrm{sec})\end{array}$ & $\begin{array}{c}\text { Layer } \\
\text { Thickness } \\
(\mathrm{km})\end{array}$ \\
\hline \multicolumn{5}{|c|}{ Southwest of Site 322} \\
\hline $\mathrm{E} 42-51$ & $-63^{\circ} 37.5^{\prime}$ & $-85^{\circ} 26.7^{\prime}$ & $\begin{array}{l}2.038 \pm 0.340 \\
2.479 \pm 0.200\end{array}$ & $\begin{array}{l}0.638 \\
0.549\end{array}$ \\
\hline $\mathrm{E} 43-5$ & $-64^{\circ} 27.1^{\prime}$ & $-81^{\circ} 29.3^{\prime}$ & $\begin{array}{l}1.573 \pm 0.171 \\
2.682 \pm 0.161\end{array}$ & $\begin{array}{l}0.312 \\
0.682\end{array}$ \\
\hline E43-6 & $-62^{\circ} 52.3^{\prime}$ & $-89^{\circ} 50.6^{\prime}$ & $1.805 \pm 0.265$ & 0.645 \\
\hline \multicolumn{5}{|c|}{ West of Site 323} \\
\hline $\begin{array}{l}\mathrm{E} 42-29 \\
\mathrm{E} 42-30\end{array}$ & $\begin{array}{l}-64^{\circ} 06.2^{\prime} \\
-63^{\circ} 51.6^{\prime}\end{array}$ & $\begin{array}{l}-104^{\circ} 18.1^{\prime} \\
-100^{\circ} 22.0^{\prime}\end{array}$ & $\begin{array}{l}1.673 \pm 0.047 \\
1.625 \pm 0.051\end{array}$ & $\begin{array}{l}0.540 \\
0.606\end{array}$ \\
\hline \multicolumn{5}{|c|}{ Nonlaminated Sediment Wedge Near Site 324} \\
\hline $\mathrm{E} 42-47$ & $-69^{\circ} 05.8^{\prime}$ & $-97^{\circ} 23.9^{\prime}$ & $\begin{array}{l}1.677 \pm 0.123 \\
2.402 \pm 0.098 \\
2.514 \pm 0.273\end{array}$ & $\begin{array}{l}0.473 \\
1.147 \\
0.565\end{array}$ \\
\hline $\mathrm{E} 42-49$ & $-68^{\circ} 18.4^{\prime}$ & $-100^{\circ} 07.3^{\prime}$ & $\begin{array}{l}1.973 \pm 0.100 \\
2.008 \pm 0.088 \\
2.332 \pm 0.182\end{array}$ & $\begin{array}{l}0.625 \\
0.680 \\
0.443\end{array}$ \\
\hline
\end{tabular}

${ }^{\mathrm{a}}$ From R. Houtz, unpublished data.

in the hole, and they may correspond to the top of the acoustically laminated sediment at $0.23 \mathrm{sec}$ in the profiler record. The acoustic lamination of the interval below $0.23 \mathrm{sec}$ is similar to that caused by interbedding of unconsolidated sand, silt, and clay in the upper 300 meters of Sites 322 and 323. If the boundary between the two units is placed at the level where silicified sediment was first recovered, a minimum average velocity of 1.66 $\mathrm{km} / \mathrm{sec}$ for the nonlaminated layer is indicated; if the boundary were as deep as Core $10(208.5 \mathrm{~m})$, the interval velocity would be $1.81 \mathrm{~km} / \mathrm{sec}$. The only direct velocity measurement was $1.60 \mathrm{~km} / \mathrm{sec}$ on consolidated clay at 176.4 meters; corrected for overburden stress, hydrostatic pressure, and temperature to in situ conditions, this value probably would be only slightly higher than the first of the above average interval velocities, suggesting that it be the better estimate. Two sonobuoy profiles recorded over nonlaminated sediments adjacent to this site (Table 7) suggest a similar low velocity; the sonobuoy closest to Site 324 (E42-47) was on the eastern edge of the nonlaminated sediment wedge; it indicates an interval velocity of $1.68 \mathrm{~km} / \mathrm{sec}$ for the upper 473 meters of sediment. The interval velocity for the nonlaminated layer alone is probably slightly lower.

The apparent reflector at $0.05 \mathrm{sec}$ probably lies at about 40 meter depth. We have no velocity or impedance measurements in this interval, but the reflector may relate to the marked changes in density and in drilling/coring rates near this level (Figure 4). The sediments in the upper 40-50 meters are lithologically dissimilar to the deeper clays in that they are enriched in diatoms and ice-rafted debris (see Site 324 Report).

\section{Site 325}

As Glomar Challenger departed Site 325, it made two seismic profiler traverses within about $0.9 \mathrm{~km}$ of the drill-hole location. These profiler records and that of 


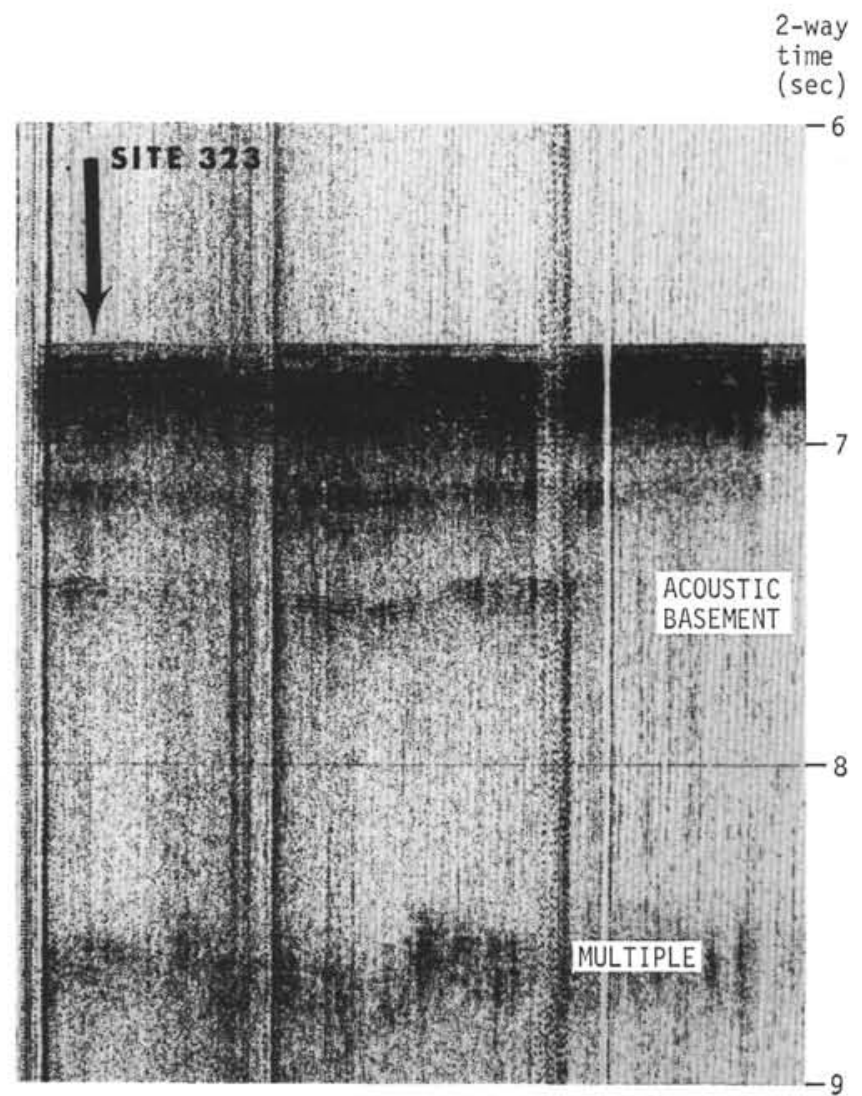

Figure 10. Glomar Challenger profiler record across Site 323 on the Bellingshausen Abyssal Plain.
Conrad 15, Leg 3, which also approached within a kilometer northwest of the site, show a sediment section thicker than at Sites 322 and 323, but similar in having an upper, acoustically laminated interval overlying mostly nonlaminated sediments (Figures 14 and 15). Acoustic basement is poorly defined in the Glomar Challenger profile, but these records and those of Conrad 15 show that it is much smoother than acoustic basement normally representing basaltic crust (Figure 15).

Conrad 15 also recorded a sonobuoy profile (R-13) just northwest of the site. Careful analysis of this record indicates that the upper $0.34 \mathrm{sec}$ of sediment has a velocity of $2.04 \mathrm{~km} / \mathrm{sec}$; the interval 0.34 to $0.96 \mathrm{sec}$ subbottom, a velocity of $2.82 \mathrm{~km} / \mathrm{sec}$; and Layer 2 below $0.96 \mathrm{sec}$, a velocity of $5.35 \mathrm{~km} / \mathrm{sec}$. In Figure 5, the reflectors from the Challenger profile are placed at depths computed from these velocities. Thus the deepest distinct reflector (here called acoustic basement) is at 1024 meters, and material with velocity characteristic of basalt $(5.35 \mathrm{~km} / \mathrm{sec})$ is at 1221 meters.

Acoustic basement in the Challenger profile near Site 325 is a reverberant horizon with its upper boundary at $0.82 \mathrm{sec}$ subbottom, $0.14 \mathrm{sec}$ above the probable basaltic material of Layer 2. Study of the full-scale Conrad record shows that coherent reflectors are present below acoustic basement (Figure 15). High-velocity sediments such as those cored shallower in the sedimentary section may overlie basaltic basement peaks, thus forming an acoustic-basement horizon which masks the basaltsediment interface (see Herron and Tucholke, this volume; Christensen et al., 1973).

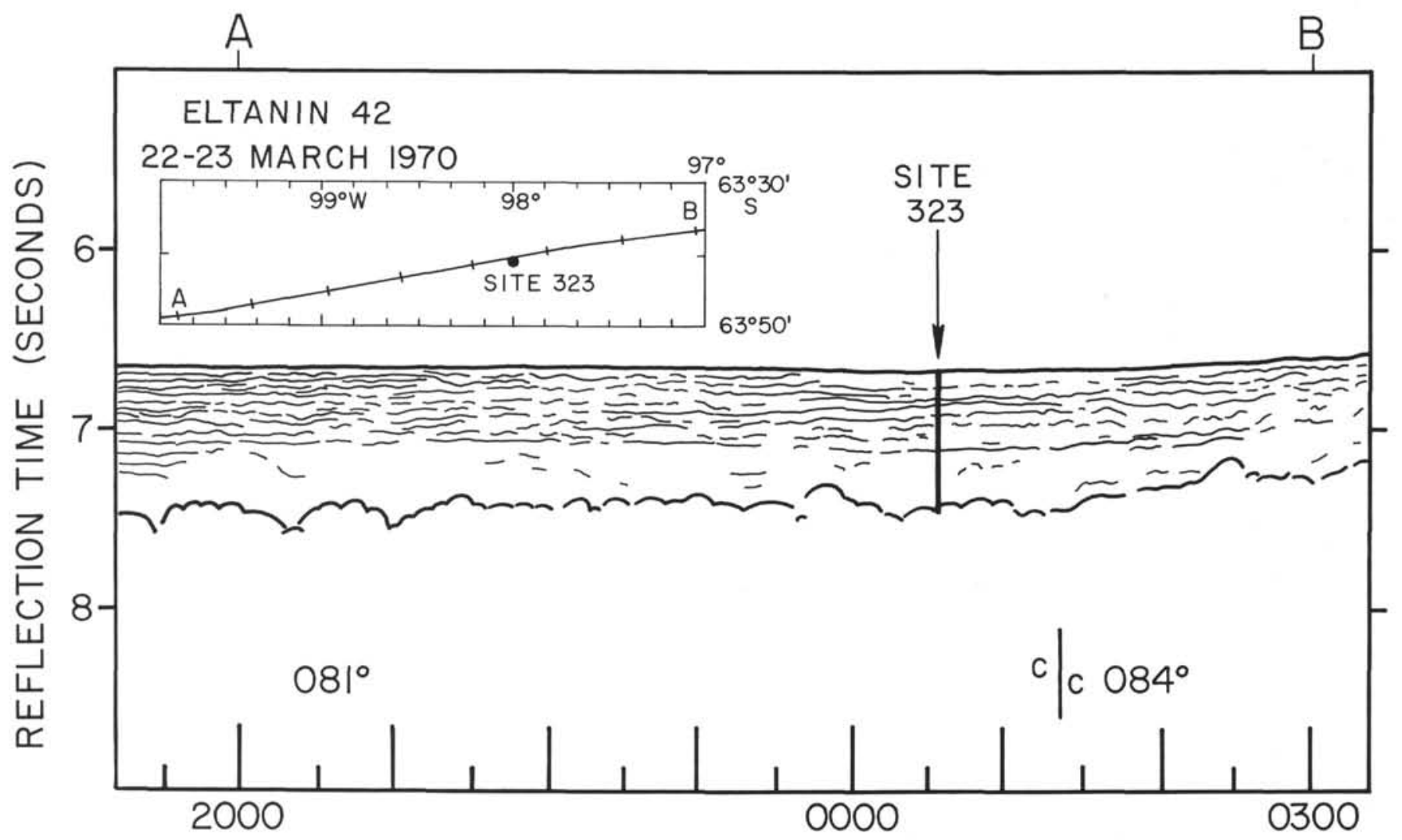

Figure 11. Tracing of Eltanin 42 profiler record near Site 323. 


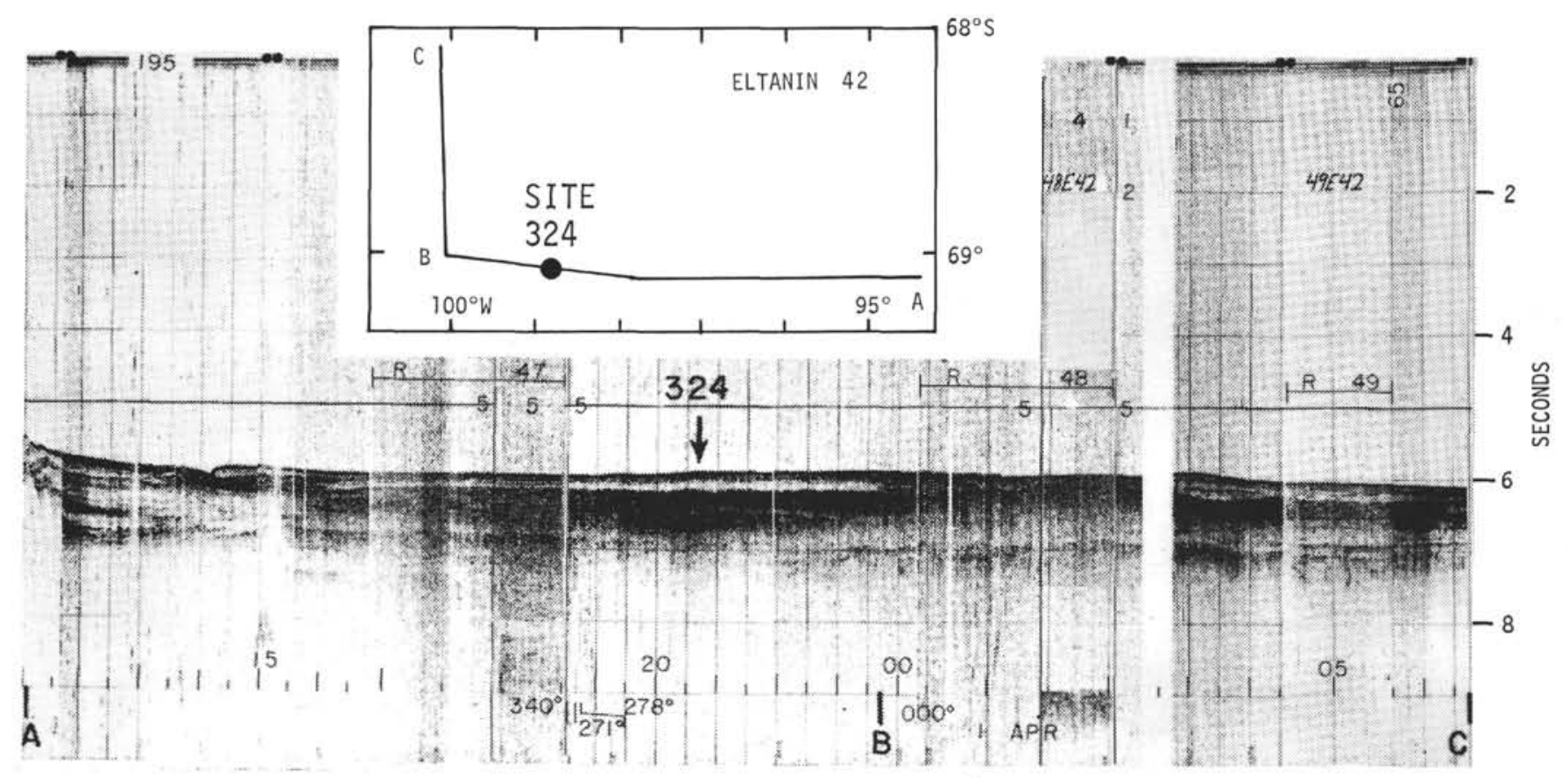

Figure 12. Eltanin 42 profiler record near Site 324 on the continental rise. Sonobuoys location are shown by " $R$ ".

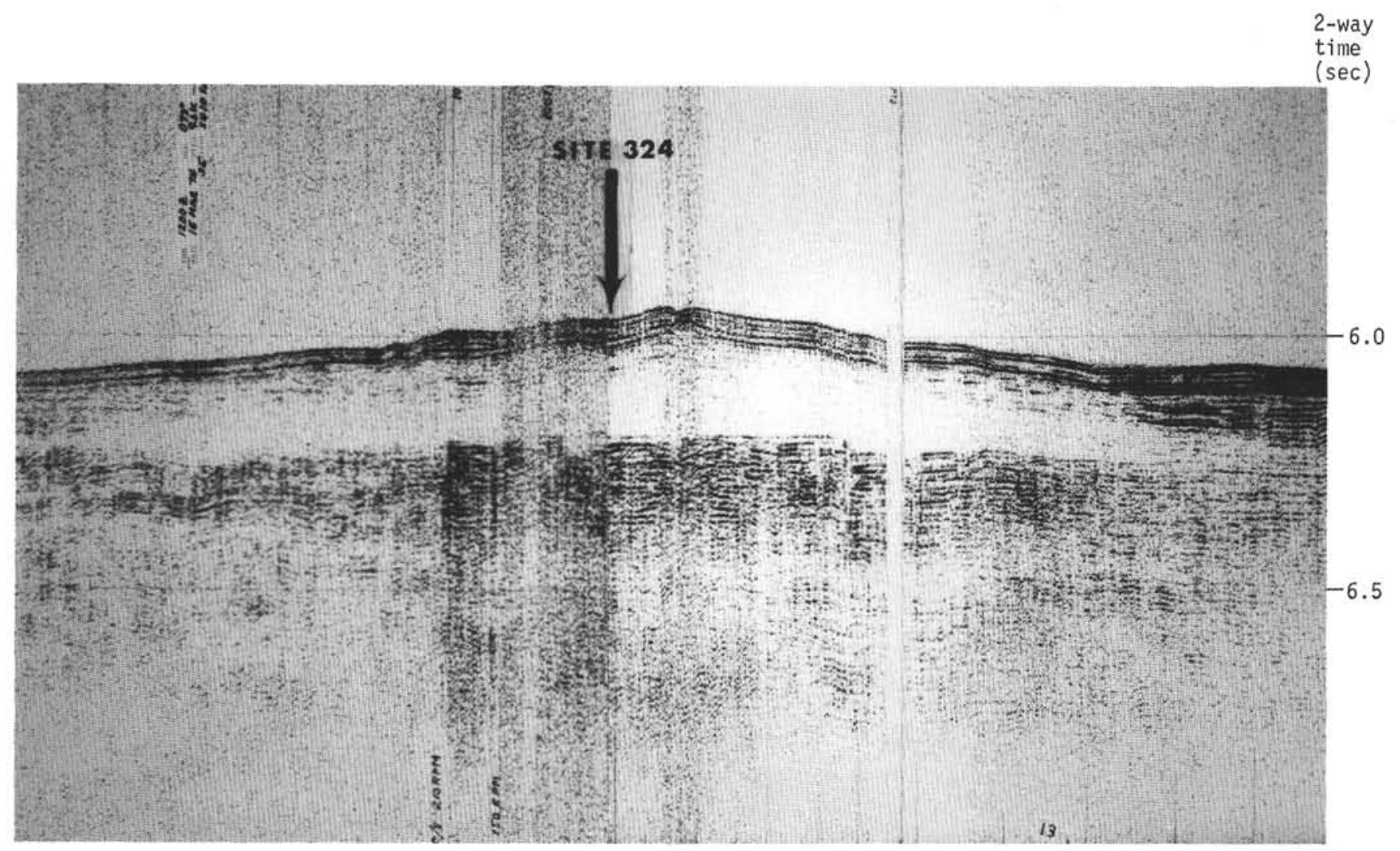

Figure 13. Glomar Challenger profiler record across Site 324 on the continental rise.

A few very faint and ill-defined reflectors appear in the nonlaminated interval above acoustic basement. The numerous silica and calcite-cemented samples recovered below 400 meters (Table 7) suggest that the weak reflectors in the nonlaminated interval are related to impedance contrasts caused by diagenetic changes. The acoustic impedance contrast indicated in Core 10 at 713 meters does not correspond to the sonobuoy-determined depth of any of these reflectors (Figure 5). However, it does match the weak reflector at 734 meters if an interval velocity of $2.66 \mathrm{~km} / \mathrm{sec}$ is assumed between $0.34 \mathrm{sec}$ and acoustic basement at $0.82 \mathrm{sec}$ subbottom. This 


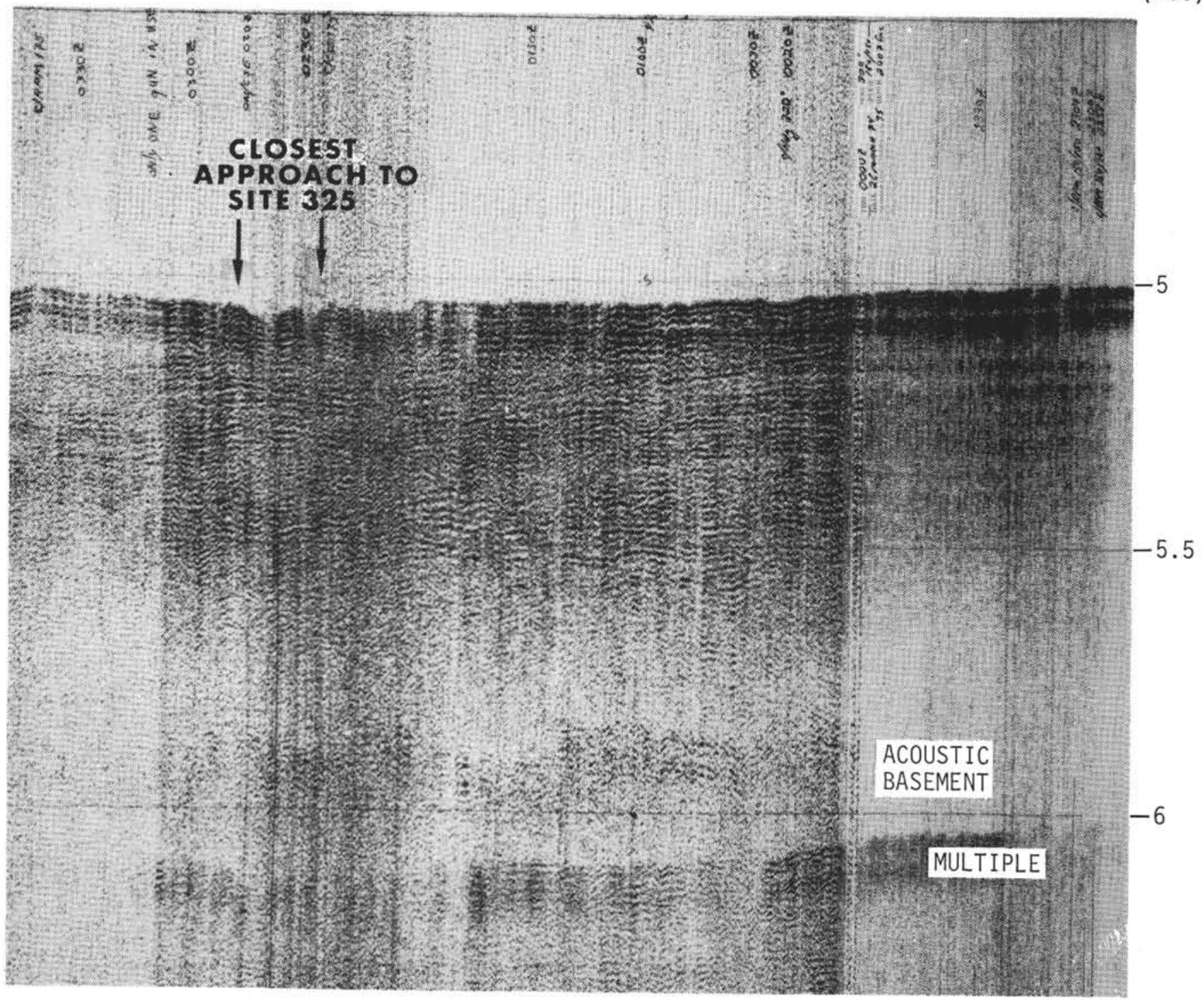

Figure 14. Glomar Challenger profiler record near Site 325.

would require an interval velocity of $3.37 \mathrm{~km} / \mathrm{sec}$ between acoustic basement and Layer 2. Both these interval velocities are reasonable in terms of the reflection record and the sediment character, but the correlation on which they are based is too tenuous to provide much certainty in the values.

The calcite-cemented siltstone recovered at 406 meters in Core 5 provides a sharp impedance contrast which correlates reasonably well with the 0.37 -sec reflector near the base of the upper, acoustically laminated interval (Figure 5). The high-velocity siltstone in this core could have come from any depth between Cores 4 and 5 because of the technique utilized throughout this interval of drilling ("washing") with an open core barrel. As an example, geochemical evidence deeper in the hole shows that Core 8 actually contains sediment from near the level of Core 7 (see Gieskes and Lawrence, this volume).
As at Sites 322 and 323, the transition from clay to claystone occurs near 300 meters, but the acoustic lamination in the profiler records extends well below this depth. However, low values of core recovery also persist to greater depths than at the first two sites (Figure 1), possibly suggesting that numerous beds of coarse unconsolidated material occur much deeper than the clay/claystone transition. The variations in mass physical properties between these unconsolidated and consolidated sediments may account for the deeper persistence of marked acoustic lamination.

\section{CONCLUSIONS}

Several generalizations can be made concerning the relationships between acoustic stratigraphy and sediment physical properties in the Bellingshausen basin.

1) The shallowest 200-300 meters of sediments at Sites 322,323 , and 325 are acoustically laminated and 


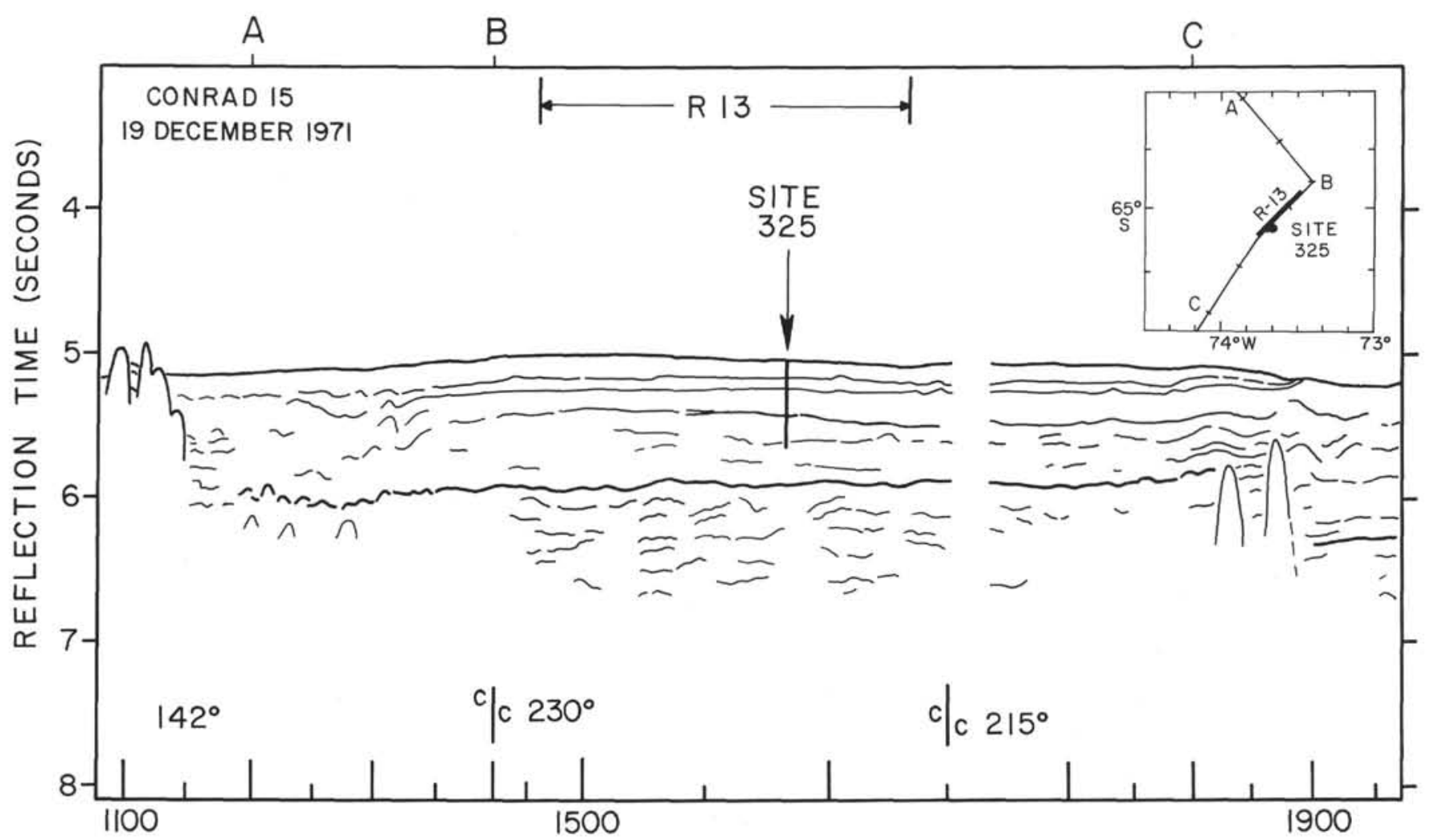

Figure 15. Tracing of Conrad 15 profiler record near Site 325. Sonobuoy location (R-13) is shown.

probably owe their seismic character to impedance contrasts created by variations in saturated bulk densities and sonic velocities due to the interlayering of unconsolidated sand, silt, and clay. Unfortunately, we cannot test this inference because the few measurements we have in this interval were all on clayey sediments. Physical properties variations diminish in the deeper, consolidated analogs of these sediments, resulting in a deep, acoustically nonlaminated interval. Shallow sequences of nonlaminated sediment, such as those observed at Site 324, probably correspond to uniform clays with only slight variations in physical properties.

2) Impedance contrasts indicated by our velocity/density measurements correlate closely with reflectors observed in the corresponding seismic profiler records. Core recovery was insufficient to test possible relationships between reflector character and such factors as thickness and configuration of high-impedance units.

3) Compressional wave velocities determined both directly on sediment samples and by sonobuoy measurements steadily increase with depth in the sediment column, but there is considerable lateral variation in velocity at any given acoustic-stratigraphic level. The semiconsolidated and consolidated sediments below about 200 meters show an average anisotropy in compressional wave velocity of $5 \%\left(\mathrm{~V}_{\mathrm{p}}\right.$ parallel $>\mathrm{V}_{\mathrm{p}}$ perpendicular) which is independent of depth. Anisotropy is generally much higher in silicified and calcite-cemented sediments.

\section{ACKNOWLEDGMENTS}

We thank G. Keller, G. Bryan, and C. Hollister for discussion and review of the manuscript and R. Houtz for the use of unpublished Eltanin sonobuoy data. Lamont-Doherty data collection was supported by the Office of Polar Programs, National Science Foundation Grant GA 12825 (Eltanin), and NSF Grant GA 27281 and Office of Naval Research Contract N00014-67-A-0108-0004 (Conrad Cruise 15, Leg 3). On Glomar Challenger, Ted Gustafson, Robert Iuliucci, and Victor Sotello were instrumental in operating and maintaining the seismic profiler and GRAPE equipment. The senior author was supported through a postdoctoral fellowship at LamontDoherty Geological Observatory during the preparation of this paper. Contribution No. 2201 of Lamont-Doherty Geological Observatory.

\section{REFERENCES}

Bennett, R.H. and Keller, G.H., 1973. Physical properties evaluation. In van Andel, T.H., Heath, G.R., et al., Initial Reports of the Deep Sea Drilling Project, Volume 16: Washington (U.S. Government Printing Office), p. 513519.

Boyce, R.E., 1973. Appendix I. Physical property methods. In Edgar, N.T., Saunders, J.B., et al., Initial Reports of the Deep Sea Drilling Project, Volume 15: Washington (U.S. Government Printing Office), p. 1115-1128.

, in press. Definitions and laboratory techniques of compressional sound velocity parameters and wet water content, wet-bulk density, and porosity parameters by gravimetric and Gamma Ray Attenuation Techniques. In Jackson, E.D., Schlanger, S.O., et al., Initial Reports of the Deep Sea Drilling Project, Volume 33, Washington (U.S. Government Printing Office).

Brier, C., Bennin, R., and Rona, P.A., 1969. Preliminary evaluation of a core scintillation counter for bulk density measurement in marine sediment cores: J. Sediment. Petrol., v. 39, p. 1509-1519.

Christensen, N.I., Fountain, D.M., and Steward, R.J., 1973. Oceanic crustal basement: a comparison of seismic proper- 
ties of DSDP basalts and consolidated sediments: Marine Geol. v. 15 , p. $215-226$.

Evans, H.B., 1965. GRAPE - A device for continuous determination of material density and porosity: SPWLA Logging Symp., 6th Ann. Trans., Dallas, Texas, v. 2, p. B1-B25.

Evans, H.B. and Cotterell, C.H., 1970. Gamma-ray attenuation density scanner. In Peterson, M.N.A., Edgar, N.T., et al., Initial Reports of the Deep Sea Drilling Project, Volume 2: Washington (U.S. Government Printing Office), p. $442-454$.

Hamilton, E.L., 1970. Sound velocity and related properties of marine sediments, North Pacific: J. Geophys. Res., v. 75, p. $4423-4445$.

1971. Prediction of in situ acoustic and elastic properties of marine sediments: Geophysics, v. 36, p. 266284.

Harms, J.C. and Choquette, P.W., 1965. Geologic evaluation of a gamma-ray porosity device: SPWLA Logging Symp., 6th Ann. Trans., Dallas, Texas, v. ii, p. C1-C37.

Horn, D.R., Horn, B.M., and Delach, M.N., 1968. Correlation between acoustical and other physical properties of deep sea cores: J. Geophys. Res., v. 73, p. 1939-1957.

Keller, G.H., 1965. Deep sea nuclear sediment density probe: Deep-Sea Res., v. 12, p. 373-376.

Keller, G.H. and Bennett, R.H., 1973. Sediment mass physical properties-Panama Basin and northeast equatorial Pacific. In van Andel, T.H., Heath, G.R., et al., Initial Reports of the Deep Sea Drilling Project, Volume 16: Washington (U.S. Government Printing Office), p. 499-512.

Kinsler, L.E. and Frey, A.R., 1962. Fundamentals of acoustics, 2nd ed.: New York (John Wiley).

Lee, H.J., 1973. Measurements and estimates of engineering and other physical properties, Leg 19. In Creager, J.S.,
Scholl, D.W., et al., Initial Reports of the Deep Sea Drilling Project, Volume 19: Washington (U.S. Government Printing Office), p. 701-719.

Manheim, F.T., Dwight, L., and Belastock, R.A., 1974. Porosity, density, grain density, and related physical properties of sediments from the Red Sea drill cores. In Whitmarsh, R.B., Weser, O.E., Ross, D.A., et al., Initial Reports of the Deep Sea Drilling Project, Volume 23: Washington (U.S. Government Printing Office), p. 887 907.

Meyers, P.V., van Sciver, W.J., and Richards, A.F., 1973. Theory of nuclear transmission densitometry applied to sedimentology and geotechnology: Unpublished manuscript.

Packham, G.H. and van der Lingen, G.J., 1973. Progressive carbonate diagenesis at Deep Sea Drilling Sites 206, 207, 208, and 210 in the southwest Pacific and its relationship to sediment physical properties and seismic reflectors. In Burns, R.E., Andrews, J.E., et al., Initial Reports of the Deep Sea Drilling Project, Volume 21: Washington (U.S. Government Printing Office), p. 495-521.

Preiss, K., 1968. Non-destructive laboratory measurement of marine sediment density in a core barrel using gamma radiation: Deep-Sea Res., v. 15, p. 401-407.

Schlumberger, 1972. Log interpretation-Vol. 1 Principles: New York (Schlumberger Ltd).

Tittman, J. and Wahl, J.S., 1965. The physical foundation of formation density logging (gamma-gamma): Geophysics, v. 22, p. 321-381.

Wahl, J.S., Tittman, J., Johnstone, C.W., and Alger, R.P., 1964. The dual spacing formation density log: J. Petrol. Tech., p. 1411-1416. 